$63-3$

TTG 6.e

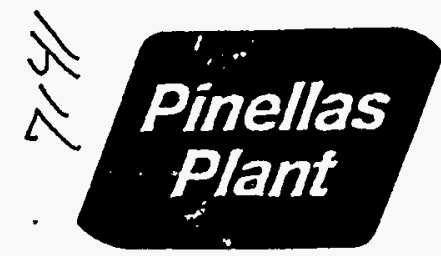

714

U.S. Department of Energy

50001655

\title{
CONDUCT OF OPERATIONS IMPLEMENTATION PLAN
}

\section{OPERATION PROGRAMS}

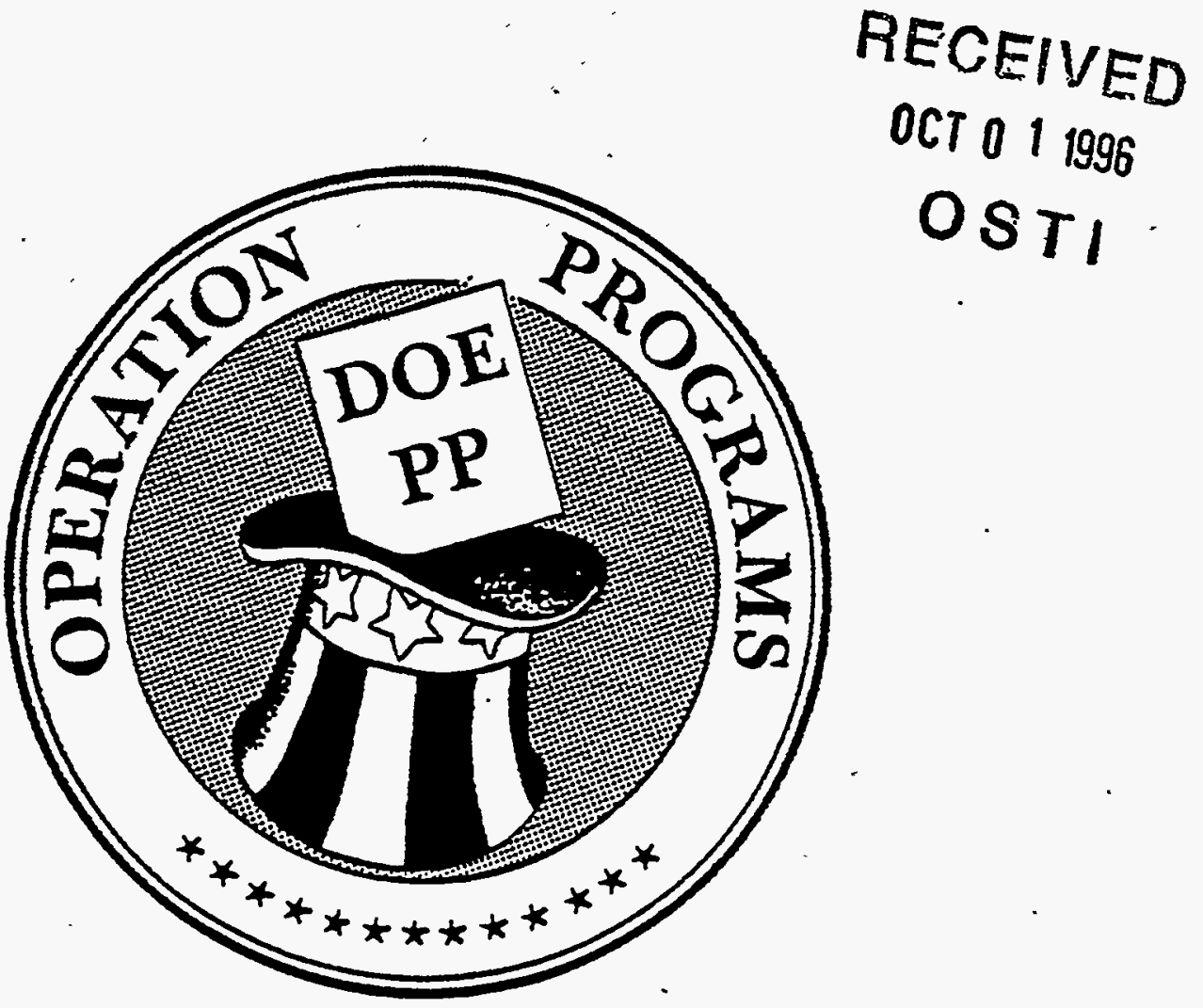

February 20, 1991

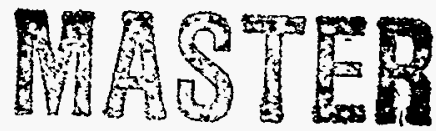

Issue 2

The Pinellas Plant

Neutron Devices Department

P.O. Box 2908

Largo, Florida 34643

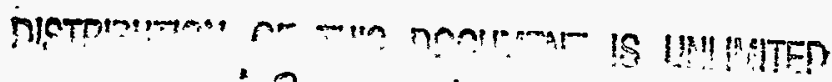


Title: $\quad$ Conduct of Operations Implementation Plan

Number: $\quad$ NDPP-OSP-0003

Issue Date: $\quad 02 / 28 / 91$

Issue Number: 2

Prepared By:

Christie K. Anderson

$\overline{\text { Date }}$

Program Manager

Raymond L. Hall

Date

Senior Technical Writer

Approved By:

Thomas P. Lavery

Date

Acting, General Manager

Virginia L. McCauley, Manager -

Date

Operation Programs 


\section{DISCLAIMER}

Portions of this document may be illegible in electronic image products. Images are produced from the best available original document. 


\section{DISCLAIMER}

This report was prepared as an account of work sponsored by an agency of the United States Government. Neither the United States Government nor any agency thereof, nor any of their employees, make any warranty, express or implied, or assumes any legal liability or responsibility for the accuracy, completeness, or usefulness of any information, apparatus, product, or process disclosed, or represents that its use would not infringe privately owned rights. Reference herein to any specific commercial product, process, or service by trade name, trademark, manufacturer, or otherwise does not necessarily constitute or imply its endorsement, recommendation, or favoring by the United States Government or any agency thereof. The views and opinions of authors expressed herein do not necessarily state or reflect those of the United States Government or any agency thereof. 
5.0 Internal References -

\subsubsection{Added Draft GOP A.1.15, "Conduct of Operations."}

6.0 Pinellas Plant Pre-Implementation Preparation -

6.2 Added "with technical guidance from the ES\&H organization."

6.2.1 Added "No High hazard areas were identified at the Pinellas Plant."

6.2.2 Added "Four Moderate hazard operations were identified: Tritium Operations, Bulk Acid Storage, LAMB Operations, and High pressure test cells."

\subsubsection{Added "18 Low hazard areas were identified."}

6.2.5 Changed "High" hazard to "Moderate" and "Moderate" hazard to "Low". Added "No High hazard areas were identified."

7.0 Implementation Plan -

7.1 Added "The committee is cross-functional with representation from ES\&H; Manufacturing; Engineering; Quality; Facilities and Programs."

7.2 Added "...establish the others as scheduled."

7.2.3 Changed "High/Moderate Hazard Team" to "Moderate Hazard Area Teams"; "This team" to "These teams"; "those guidelines" to "the guidelines"; removed "that are not identified as plantwide guidelines"; removed "to these areas"; changed "each area" to "the area"; removed "developing policies"; changed "procedures" to "activities."

7.3 Added "NOTE: A description of these teams is best seen in Attachment B."

7.4 Changed "compliance" to "conformance." Added "A detailed Pinellas Plant conformance matrix assessing current operating practices..."

7.5 Added Applicability Matrix paragraph.

7.6 Added Pilot Area paragraphs.

8.0 Conduct of Operations Manual - Added entire "Conduct of Operations Manual" text in 8.0, 8.1 and 8.2. Communications and Training became section 9.0 and subsequent sections were moved up in number accordingly.

9.0 Communication and Training Strategy - (Formerly Section 8.0)

9.1.2 Added "A video will be used as a primary communication and education tool..." 


\section{CONDUCT OF OPERATIONS IMPLEMENTATION PLAN REVISIONS}

DATE: $\quad$ February 28, 1991

TO: $\quad$ NDPP-OSP-0003, Issue 2 Distribution

FROM: Raymond L. Hall

Senior Technical Writer, Operation Programs

Area 134, MS 009, Ext. 6323

SUBJECT: Conduct of Operations Implementation Plan

NDPP-OSP-0003, Issue 2 Revisions, February 20, 1991

The first issue of the Conduct of Operations Implementation Plan (NDPP-OSP-0003) was distributed in November 1990. We have now reissued the document in response to all of the AL comments. Listed below are changes to the first issue of NDPP-0SP-0003 that appear in Issue 2, dated February 20, 1991.

\section{Front Matter -}

Title Page - Changed date from November 9, 1990 to February 20, 1991. Added logo and changed fonts.

Prepared By/Approval Page - Added to Issue 2.

Table of Contents - Revised, distribution added

Index of Attachments - Area map removed, Budget added

Note: Page numbers were added to the entire Issue 2 document, including attachments. Also dates and verb tenses within the Issue 2 document were revised to conform to the February date. Issue 2 was printed entirely on "DRAFT" paper.

1.0 Purpose - no changes

2.0 Scope -

2.1 Revised sentence "...developing policies for each applicable guideline; and establishing area specific teams to accomplish implementation.

2.4 Added "Development of Conduct of Operations Manual."

3.0 References - No changes

4.0 Definitions - No changes 
10.0 Formality of Operations (AL)/Self Assessment Requirements - (Formerly Section 9.0) Added introductory paragraph beginning with "A number of DOE requirements overlap with DOE Order 5480.19 including..."

10.5 Added "This plan also meets the requirements of DOE Order 5480.10, Chapter VI, "Investigation of Abnormal Events."

10.10 Changed "will be attending" to "attended the Maintenance Program implementation guidance meetings held at the AL Complex in November 1990 and January 1991.

11.0 Implementation Schedule - Attachment $G$ changed to Attachment $F$ and Attachment $\mathrm{H}$ changed to Attachment $\mathrm{G}$, because one of the attachments, area maps, was removed from Issue 2.

12.0 Budget - Added to Issue 2, not found in Issue 1.

13.0 Conclusion - No changes except this was section 11 in Issue 1.

14.0 Distribution - Added S. Taylor, DCM System and the Conduct of Operations Committee to the distribution list.

Attachment A - Pinellas Plant Ownership Areas - The original Attachment A, found in Issue 1, was deleted because it was no longer accurate. It was replaced with an updated list of ownership areas, Pinellas Plant Area Report.

Attachment B - Pinellas Plant Individual Area Maps - The original Attachment B, found in Issue 1, was deleted because it was no longer accurate. The area maps were not replaced.

Attachment C - Conduct of Operations Organization and Task Breakdown - The original Attachment $C$, found in Issue 1, was amended to include training responsibilities of the Conduct of Operations Committee. This became Attachment B in Issue 2.

Attachment D - Compliance Matrix by Category - Unchanged. Became Attachment $\mathrm{C}$ in Issue 2.

Attachment E - Specific Compliance Matrix By Ownership Area - Unchanged. Became Attachment D in Issue 2.

Attachment F - Newsletter - Updated to include latest newsletter. Became Attachment $E$ in Issue 2.

Attachment G - Implementation Schedule - Revised schedule based on AL comments and added Reference Page linking individual tasks on the graph to a paragraph in the plan. Became Attachment F in Issue 2.

Attachment H - Implementation Strategy - Unchanged. Became Attachment G in Issue 2.

Added new Attachment $\mathrm{H}$, Budget, to Issue 2. 


\section{TABLE OF CONTENTS}

TITLE

PAGE

1.0 PURPOSE

2.0 SCOPE 1

3.0 REFERENCES

4.0 DEFINITIONS _ : 3

5.0 INTERNAL REFERENCES . 4

6.0 PINELLAS PLANT PRE-IMPLEMENTATION PREPARATION 4

7.0 IMPLEMENTATION PLAN

8.0 COMMUNICATIÓN AND TRAINING STRATEGY 7

9.0 REQUIREMENTS FOR FORMALITY OF OPERATION (AL) 8

10.0 IMPLEMENTATION SCHEDULE 9

$\begin{array}{ll}11.0 & 13\end{array}$

$\begin{array}{ll}12.0 \text { BUDGET . } & 14\end{array}$

13.0 CONCLUSION 14

$\begin{array}{lll}14.0 & \text { DISTRIBUTION } & 15\end{array}$ 


\section{INDEX OF ATTACHMENTS}

PAGE

Attachment A Pinellas Plant Area Report

Attachment B Conduct of Operations Organization and Task Breakdown

Attachment C . Compliance Matrix By Category

Attachment D Specific Compliance Matrix By Ownership Area

Attachment E Newsletter

Attachment F Implementation Schedule

Attachment G Implementation Strategy

Attachment $\mathrm{H}$ : Budget 


\subsection{PURPOSE}

This implementation plan describes the process and provides information and schedules that are necessary to implement and comply with the Department of Energy (DOE) Order 5480.19, "Conduct of Operations" (CoOp).

\subsection{SCOPE}

This plan applies to all Pinellas Plant operations and personnel. Generally, this Plan discusses how DOE Order $\mathbf{5 4 8 0 . 1 9}$ will beimplemented at the Pinellas Plant. Specifically, this plan addresses the following items:

2.1 The formation of a number of Conduct of Operations teams aimed at overseeing the plantwide implementation of CoOp; defining ownership areas; dividing those areas into three categories of hazard (High, Moderate, and Low) consistent with DOE Order 5481.1B; developing .policies for each applicable guideline; and establishing area specific teams to accomplish implementation.

2.2 Current status of compliance to CoOp guidelines.

2.3 Communication and Training Strategies.

2.4 Development of a Conduct of Operations Manual

2.5 Current compliance to the AL requirements for Formality of Operation.

2.6 Implementation strategies to comply with DOE Order 5480.19.

2.7 Implementation schedule.

\subsection{REFERENCES}

3.1 DOE Order 5480.19, "Conduct of Operations Requirements for DOE Facilities".

3.2 Memorandum from Bruce G. Twining to Managers, DOE Operations, "Implementation of Department of Energy 5480.19, Conduct of Operations Requirements for Department of Energy Facilities", WMCSD, September 12, 1990.

3.2.1 Attachment 1, "Guidance on Implementation Plans for DOE 5480.19 , Conduct of Operations Requirements for DOE Facilities and AL Weapon Facilities Operating Principles". 
3.2.2 Attachment 2, Memorandum from Bruce Twining to Managers, DOE Operations, "AL Weapon Facilities Operating Principles", WMOSD, February, 27, 1989.

- $\quad$ Attachment, "Albuquerque Operations Office Weapon Facilities Operating Principles", I. INTRODUCTION, II. REQUIREMENTS FOR FORMALITY OF OPERATIONS, III. RESPONSIBILITIES, IV. DEFINITIONS.

3.2.3 Attachment 3, Memorandum from Harry T. Season Jr. to Managers, DOE Operations, "Institute of Nuclear Power Operations (INPO)", WMOSD:OSP:MSB, February 27, 1990.

3.3 Memorandum from John R. Kirby to J.B. Neale, Manager, Programs Section, GEND-019, "Evaluation of Continued Safe Operations, Phase I: Hazards Audit", PAO:RAl:OPS013, August 27, 1990

3.3.1 Memorandum from K.A. Carlson to Managers, DOE Operations, "Evaluation of Continued Safe Operations, Phase I: Hazards Audit", WMOSD:SARB:GJW, August 14, 1990.

3.3.2 Letter from John B. Neale to John R. Kirby, "Evaluation of Continued Safe Operations, Phase 1: Hazards Audit", OPS:VLM:0921AL7, September 21, 1990.

- Hazards Audit

- Conduct of Operations - Documentation Matrix

3.4 DOE Order 5481.1B, "Safety Analysis and Review System".

3.5 AL Order 54XA, "Operational Readiness Reviews (ORRs)"

3.6 DOE Order 5700.6B, "Quality Assurance"

3.7 DOE Order 4330.XXX, "Conduct of Maintenance"

3.8 DOE Order 5482.1B, "Environmental, Safety, and Health Appraisal Program" 


\subsection{DEFINITIONS}

4.1 Line Manager - Any manager who has direct responsibility for a physical area or personnel.

4.2 Line Management - Refers to any manager who is directly responsible for operational and programmatic activities. This chain of command flows from the first line manager through the General Manager, and to area and operations office managers who ultimately report to $\mathrm{DOE} / \mathrm{HO}$.

4.3 High Hazard Area - An area with the potential for on-site or off-site impacts to large numbers of persons or for major impacts to the environment.

4.4 Moderate Hazard Area - An area which presents considerable potential for on-site impacts to people or the environment, but at most only minor off-site impacts.

4.5 Low Hazard Area - Those areas which present minor on-site and negligible off-site impacts to people or the environment.

4.6 All Other Areas - Any area that does not fit into the category of a high, moderate or low hazard.

4.7 Ownership Areas - The entire plant is divided into areas and an owner has been identified for each of these areas (See Attachment A). Additionally, ownership has been established for anything above the ceiling and below the floor. 


\subsection{INTERNAL REFERENCES}

5.1 Neutron Devices Department General Operating Procedure Manual 5.1.1 GOP A.1.15, "Conduct of Operations"

5.2 Neutron Devices Department Environmental, Health and Safety Manual

5.3 Neutron Devices Department Waste Management Operating Procedures Manual (GEPP-SP-818)

5.4 Neutron Devices Department Environmentál Monitoring Procedures Maniual

5.5 Neutron Devices Department Environmental/ Waste Management Quality Program Plans

\subsection{PINELLAS PLANT PRE-IMPLEMENTATION PREPARATION}

Prior to developing an implementation plan for the 18 CoOp guidelines, GEND management identified a need to develop formal "Ownership Areas" and to categorize these areas based on the potential hazards of the area. As a part of this implementation plan, specific owners have been identified by name and title. These owners have total responsibility for implementing all new orders and requirements within their area in addition to the normal daily requirements of the area.

6.1 Establishment of Ownership Areas - The plant has been divided into - individual areas (See Attachment A). A cross functional team (Ownership Area Team) identified each area, categorized the areas based on hazard, and identified specific owners. These divisions have become the backbone to the implementation and management of the business including CoOp.

6.2 Categorization of Areas - Once the areas were identified, the Ownership Area Team with technical guidance from the EH\&S organization categorized each into one of the following categories:

6.2.1 High Hazard Area - An area with the potential for on-site or offsite impacts to large numbers of persons or for major impacts to the environment.

- $\quad$ No high hazard areas were identified at the Pinellas

Plant. 
6.2.2 Moderate Hazard Area - An area which presents considerable potential for on-site impacts to people or the environment, but at most only minor off-site impacts.

- Four moderate hazard operations were identified:

- Tritium Operations

- $\quad$ Bulk Acid Storage

- $\quad$ LAMB Operations

- High pressure test cells

6.2.3 Low Hazard Area - Those areas which present minor on-site and negligible off-site impacts to people or the environment.

- 18 low hazard areas were identified

6.2.4 All Other Areas - Any area that does not fit into the category of a High, Moderate or Low hazard.

6.2.5 The implementation of CoOp will be graded with the highest priority given to moderate hazard areas, then the low hazard areas, etc. (No high hazard areas were identified).

6.3 Identification of Owners - Each area is owned by a specific manager. This manager is held accountable for everything associated with that area including the CoOp principles.

\subsection{IMPLEMENTATION PLAN}

\subsection{CoOp Committee (involvement)}

The implementation of CoOp is being guided and overseen by the CoOp Committee (See Attachment B). This committee will continue to establish all other teams necessary to plan and implement CoOp. The basic thrust of this team is to ensure that all practices are implemented with the best interest of the business in mind; to involve as many employees as possible in the planning (to create ownership); and to ensure that GEND meets or exceeds the CoOp requirements. The committee is cross-functional with representation from ES\&H; Manufacturing; Engineering; Quality; Facilities and Programs. 


\subsection{Sub-Teams -}

The CoOp Committee has already established two subteams and will establish the others as scheduled.

7.2.1 Ownership Team - A cross-functional team that defined ownership areas; categorized the areas based on hazard, and identified specific owners.

7.2.2 Plantwide Guidance Team - This team will review the CoOp guidelines and develop and document policies for each of these guidelines.

7.2.3 Moderate Hazard Area Teams - These teams will be responsible for reviewing the guidelines for applicability; assessing the current level of compliance within the area; ensuring appropriate documentation; implementing the guidelines; and recommending appropriate surveillance activities.

7.2.4 Low Hazard Area Teams - These teams will do the same things as the moderate team except in conjunction with areas categorized as low hazard.

7.2.5 All Other Area Teams - These teams will do the same things as the low hazard team except in conjunction with areas not falling into any other category.

7.2.6 Members of The Area Teams will be "experts" from areas categorized as moderate, low or all other. They may be hourly, non exempt, or exempt employees.

7.3 Guideline Teams - These teams can be formed by any area team to concentrate on developing compliance strategies for a particular guideline. For example, the Plantwide Guidance team may feel it is necessary to form a guideline team for the policy and procedure development on control room activities. These people will most probably be representatives from the control rooms. Again, an effort to involve and create ownership.

NOTE: A description of these teams is best seen in Attachment B.

7.4 Conformance Matrix - A detailed Pinellas Plant conformance matrix assessing current operating practices against each guideline will be completed in March 1991. A generic conformance matrix can be found in Attachment C. 
7.5 Applicability Matrix - The applicability matrix addresses each of the 135 guidelines in relation to each of the areas of the facilty. The applicability matrix in Attachment $D$ will be updated to include a detailed area by area, paragraph by paragraph analysis of applicability. Justification for non-applicability will be included. The scheduled completion date for the updated matrix is the end of May, 1991.

7.6 Pilot Area - The pilot area for conduct of Operations at the Pinellas Plant is the Industrial Wastewater Neutralization Facilitý. A team consisting of a Utilities Engineer, the area Utilities Foreman, the area Utilities Operator, a Project engineer, a Facility computer Specialist and the Resources Planning Manager was formed. Further, a Technical Writer was hired to develop and update all procedures and operating instructions for the Wastewater Neutralization Facility.

Significant physical improvements to the facility have begun. These include: in-ground storage tank agitation, $\mathrm{pH}$ interlock system, high water level overflow system, new chart recorders, chemical feed system upgrade, instrumentation upgrade and a rearrangement of the operation building. In addition, progress in the implementation of Conduct of Operations guidelines has been made. A standardized procedure format has been developed; new procedures have been written and existing procedúres upgraded, logbooks have been standardized, a training program is under development, equipment and piping labeling is nearly complete, an improved system for shift turnover is being investigated, and a long range staffing plan is being generated. Full implementation of Conduct of Operations in this area is scheduled for July, 1991.

\subsection{CONDUCT OF OPERATIONS MANUAL}

8.1 Plant-wide Manual - The Plant-Wide Conduct of Operations Manual will be in the following format:
$\bullet$ A Title Page, Document Number and Tracking System, Date and Issue Number.
- An author and Approval Page
- A Table of Contents
- $\quad$ Consistent Headings and Subheadings, each paragraph numbered, each page numbered, and each page dated for revision tracking. 
8.1 Continued...

- A distribution list of Manual recipients with an automatic copy going to the Technical Information Center and the Document Control Management System. The master copy of the manual will be retained and filed by Operation Programs Subsection.

- The manual will be printed and bound with emphasis on legibility, durability and ease of use.

- The Functional Areas of the Pinellas Plant will be identified with maps and descriptions.

- The manual will follow the eighteen chapters of the DOE Order, and the guidelines within each chapter, to identify and define the Conduct of Operations Policy and General Procedures for the Pinellas Plant.

8.2 Specific Area Manuals - Specific Area Conduct of Operations Manuals will be created by the specific areas of the Pinellas Plant. These manuals will be inserted in the section's Plant-Wide Manual, making the manual unique to that section.

8.2.1 Specific Procedures for individual functional areas will be addressed by Area Conduct of Operations Manuals which will be referenced by document number in the plant-wide manual.

8.2.2 Copies of all area manuals will be included in the Master Plantwide Conduct of Operation Manual and the copy located in the Technical Information Center.

8.2.3 The Plant-wide Manual will include a tab where each individual area can insert their area manual. Thus, each area will have a copy of the Plant-wide Manual, references to all area manuals by document number, but only their specific area (sub)manual will be inserted in their Plant-wide Manual.

\subsection{COMMUNICATIONS AND TRAINING STRATEGY}

The foundation for effective implementation of CoOp is strong communications and training programs. Both will be formally planned, documented and implemented as a part of the implementation. 
9.1 Communications - The concepts of $\mathrm{CoOp}$ and other operational surety programs will be communicated through a variety of avenues in an attempt to reach all employees.

9.1.1 One of the first and most regular modes of communication will be a monthly newsletter (See Attachment E). This newsletter will be distributed to all employees. It will include bits and pieces of information related to operational surety, specifically: information on 5000.3A incidents, new CoOp programs being implemented, recognition of employees for outstanding contributions in the operational surety arena, and general educational materials.

9.1.2 A video will be used as a primary communication and education tool throughout the implementation of DOE Order 5480.19. The initial introduction to Conduct of Operation concepts will be completed and presented in March 1991. This medium will continue to be used as specific guidelines are developed and implemented.

9.1.3 The Bi-Weekly Management Stand-Up Meetings and the Headliner newsletter will continue to be used as a method of communicating CoOp information.

9.1.4 Most importantly, the basic precepts of CoOp will be woven into the organization through involving as many employees, at as many levels as possible, in the implementation and development of CoOp guidelines.

9.2 Training - A formal training program will be developed by qualified performance based technologists for each of the guidelines included in CoOp. Anyone required to comply with these guidelines will be trained and tested on their knowledge. A specific training schedule and plan will be developed by each of the teams as a part of the implementation plan.

9.2.1 Overall CoOp training will be necessary to influence the cultural change to a more formal method of operations. Video tapes, area visits, one-on-one discussions, management roundtables and small group meetings will be held to stimulate this change.

9.2.2 The CoOp Committee will be held accountable for ensuring that appropriate training occurs across all CoOp programs. 


\subsection{FORMALITY OF OPERATIONS (AL)/SELF ASSESSMENT REQUIREMENTS .}

A number of DOE requirements overlap with DOE Order 5480.19 including the Self Assessment requirements and the AL Weapons Facilities Operating Principles. There is a sepearate Self Assessment Plan (NDPP-OSP-0014) that meets the requirements outlined in Chapter X of DOE Order 5480.19. The Conduct of Operations Manual will also include the Pinellas Plant Self Assessment requirements. Likewise the AL Weapons Facilities Operating Principles will be an integral part of Conduct of Operations implementation and documentation. Current conformance to Weapons Facilities Operating Principles follows:

10.1 Organization And Administration - The Pinellas Plant will update and . revamp the Functional Organization. Manual. This manual outlines duties, responsibilities, and functions of organizational units. The authority and jurisdiction of each unit, as well as the interface among units, will be clearly defined.

10.1.1 Most importantly the ES\&H responsibilities of each line organization and the ES\&H functional organization (ES\&HP) will be delienated. - For example, the revised Functional Organization Manual will state organization and position responsibilities for SARs, appraisals, and all other ES\&H activities. The critical EH\&SP functions such as technical support and consulting, and oversight responsibility will be emphasized.

10.1.2 GÉND expects to complete the revision of the Functional Organization Manual during fiscal year 1991. This manual will be reviewed and updated every two years beginning in fiscal year 1993.

10.1.3 The program for the implementation of DOE Order 5480.19, "Conduct of Operations", is designed to ensure that all operations and administrative processes are conducted in a formal manner. Several Conduct of Operations Teams will be formed to oversee plantwide implementation. One of these teams, known as the Area Definition Team, will review and update existing area maps and identify owners for each area. The completed maps will define and document facility ownership. 
10.2 Training And Qualification - A training and education subsection was formed to meet DOE training and qualification requirements. A training program is being developed and implemented in accordance with a training policy/procedures manual and a detailed training program implementation plan. The program is auditable, performance based, and adheres to the principles discussed in DOE Order 5480.18, "Accreditation Of Performance Based Training" and 5480.19 Chapter V, "Control of On-Shift Training." A training record management system has been developed; staffing is near completion; and the first phase of the implementation plan, needs assessment, has been initiated.

10.3 Continuous Improvement - In 1989, GEND, working with corporate consulting, piloted continuous process improvement (CPI) projects. Although, these initial efforts were successful and follow-on projects yielded benefits; it was recognized that broader based management support and improved facilitation and training were necessary to produce a meaningful culture change. A multifunctional subsection steering team is selecting a vendor who will assist in the development of a strategy designed to involve all GEND employees in the implementation of CPI. A key element of this strategy is the application of CPI not just to the production and administrative process but to the operational surety and ES\&H initiatives as well.

10.4 Surveillance - The design and implementation of an Environmental, Safety, and Health Self Assessment Program was recently begun at the Pinellas Plant. This program will meet the requirements of doe order 5482.1B, "Environmental, Safety, and Health (ES\&H) Self-Assessment". Elements of the plan are:

- $\quad$ Procedures For Self-Assessment

- A Reporting, Tracking and Corrective Action System

- A Root Cause, Trend Analysis, and Lessons Learned System, and

- A Formal Training Program

10.4.1 Quality Appraisal - The quality appraisal organization, has expanded its staff to include quality appraisal engineers specializing in general operations programs.

10.4.2 Environmental, Health and Safety - ES\&H conducts an appraisal program scheduling safety, fire, industrial hygiene, health physics, and environmental protection audits in all areas of the Pinellas Plant. 
10.5 Event Reporting and Resolution - The implementation of DOE Order 5000.3A has resulted in systematic event reporting. A Program Manager, responsible for coordinating GEND's Occurrence Reporting Program, interfaces with line operations and designated facility managers to ensure that all events and conditions are reported accurately. A team has been organized to perform root cause analysis for all known events and incidents. A key member of that team, the safety analysis manager, has been trained in the Management and Oversight Risk Tree (MORT) methods. Other members of the team have attended an in-house class hosted by GEND during December, 1990. This plan also meets the requirements of DOE Order 5480.10, Chapter VI, "Investigation of Abnormal Events."

10.6 Safety and Health - The Environmental Health and Safety Programs

- organization's mission is to implement formal health and safety programs as required by the Department of Energy and Government agencies. This organization will be staffed by specialists in safety, fire, industrial hygiene, health physics and environmental protection. In addition, the training organization is committed to provide performancebased training to ensure that employees have the skills and knowledge necessary to work safely, protect the environment, and comply with Federal, State, local, and plant requirements.

10.7 Protection of Emplovees; The Public and the Environment -

$A^{\prime}$ multifunctional team is developing methods and techniques for identifying all ES\&H risks in GEND processes. Identified processes will be prioritized according to hazard and studied to determine specific attributes and characteristics. The results of this investigation will be utilized by a vendor to perform risk assessment analyses and write risk assessment and safety analysis reports.

10.7.1 Operational Safety Requirements Documents will be produced as required.

10.7.2 The methodology selected for the analysis of processes will also be used to identify opportunities for waste minimization. Information pertaining to POTW discharges, tritium, and krypton releases, tritium bioassays and dosimetry are a part of GEND's performance indicator system, provided to DOE monthly.

10.8 Emergency Preparedness - Emergency operations at the Pinellas Plant are coordinated by the emergency operations center (EOC) and the satellite command posts. The EOC is a dedicated facility that provides overall command and control of the emergency response, while the satellite command posts coordinate specific aspects of the response such as deployment of response personnel, staging of equipment, and logistical assistance. The EOC is responsible for the publication of the Pinellas Plant master emergency plans and the emergency action plan. 
10.9 Operational Readiness Reviews - The Pinellas Plant is studying AL order 54XA to determine applicability and compliance.

10.10 Maintenance - The Pinellas Plant Facilities Maintenance Organization is currently operating to AL Order 4330.4, "Handbook for Maintenance of Property". Although DOE Order 4330.XX, Maintenance Management Program", is still in draft form, the Pinellas Plant is already initiating programs to assure compliance. The Program Manager responsible for program design and implementation attended the Maintenance Program implementation guidance meetings held at the AL Complex in November 1990 and January 1991.

10.10.1 The Pinellas Plant is committed to a proactive maintenance philosophy and the formal tracking and documentation of all maintenance activities. Department maintenance policy is defined the Department's General Operating Procedures. Maintenance procedures are specified in the Plant Facilities Operating Instructions. A comprehensive on-line as-built database of the facility is being compiled. An automated scheduling; storage and retrieval system provides tracking and analysis of preventive maintenance requirements.

Documented formal facilities inspection is conducted on a scheduled basis. Maintenance history records and inspection data are analyzed and used to determine repair versus replacement decisions.

10.10.2 Data derived and analyzed from inspections, repair and preventive maintenance history is also used to develop and prioritize Department refurbishment projects. Aggressive utilization of the Facilities Capability Assurance Program to fund major projects assures that the facility will maintain an excellent readiness to serve.

10.11 Quality Assurance - Quality Control and Consulting is expanding its program of general operations surveys to ensure that formal programs exist for all significant plant operations. The quality appraisal group provides oversight and guidance regarding the quality principles, criteria, and requirements published in the Quality Criteria (OC-1) and Quality Criteria (QC-2) by the Department of Energy. The requirements of DOE Order 5700.6B will be met by the Pinellas Plant. OC\&C will assure compliance to DOE Order $5700.6 \mathrm{~B}$ through audits. 
10.12 Interactions With Outside Agencies and the Public - The Manager for Public Affairs directs the public information and Public Affairs Program at GEND. All responses to the media and inquiries from the general public are coordinated with the local pinellas area office public affairs specialist.

10.12.1 Contacts with outside agencies, such as OSHA and the State of Florida, are managed by the Environmental, Health and Safety Programs Organization. EH\&SP management notifies PAO of any contacts with outside agencies and coordinates all interactions with the PAO Safety Engineer and the Environmental Compliance Manager.

\subsection{IMPLEMENTATION SCHEDULE}

Each CoOp team will be responsible for developing implementation schedules for their respective area. These schedules will be fed into a project management tool that will roll-up all schedules into one overall implementation plan. A basic implementation schedule for the establishment of the teams and a number of key milestones is included in Attachment F. . An implementation strategy is depicted in Attachment G.

\subsection{BUDGET}

The budget for implementation includes both Full Time Employees (FTE's) and other dollars necessary. It can be found in Attachment $H$.

\subsection{CONCLUSION}

The foundation built through employee involvement within this Implementation Plan is aimed not only at complying with the 18 guidelines outlined in the CoOp Order, its thrust is to capture the true intent of Formality of Operations and weave it into the daily operations and mindset of the plant. Changing a culture that has been prevalent for over 30 years is not a one-year project. Therefore, this Implementation Plan is only a small part of a much larger Operational Surety Program. 


\subsection{DISTRIBUTION}

\section{DOE}

J. Kirby - PAO

A. Banks - PAO

\section{GEND}
C.Anderson
J. Neale
V. McCauley
S. Taylor, DCM System CoOp Committee

Technical Information Center Operation Programs

$(2+$ Reproduction Masters) 
ATTACHMENT A 


\begin{tabular}{|c|c|c|}
\hline & Area & Ownex \\
\hline & & o George \\
\hline & 1000 & S Mea \\
\hline & $102 \mathrm{M} \times x$ & A Summerford \\
\hline & $\begin{array}{l}103 \\
103 \mathrm{M}\end{array}$ & $\begin{array}{l}\text { R Jones } \\
\text { M Royo }\end{array}$ \\
\hline & 104 & T Albaugh \\
\hline & 1040 & s Meo \\
\hline & 105 & T Albaugh \\
\hline & $105 \mathrm{M}$ & R Cabo \\
\hline 1 & $\begin{array}{l}105 \mathrm{M} \\
105 \mathrm{M} \times \mathrm{x}\end{array}$ & D Turner \\
\hline & 1050 & $\begin{array}{l}\text { A summerrora } \\
\text { R Cabe }\end{array}$ \\
\hline & $\begin{array}{l}105 x x \\
106\end{array}$ & $\begin{array}{l}\text { o George } \\
\text { D Sharlow }\end{array}$ \\
\hline & $106 \mathrm{M}$ & M Royo \\
\hline & 107 & H Foods \\
\hline & $\begin{array}{l}107 M \\
108\end{array}$ & A summerford \\
\hline & $108 \mathrm{~A}$ & NH Parsons \\
\hline & $108 \mathrm{~B}$ & WE Swartz \\
\hline & $108 \mathrm{~B}$ & NH Parsons \\
\hline & $\begin{array}{l}108 \times x \\
109\end{array}$ & $\begin{array}{l}\text { C Carter } \\
\text { L Hogans }\end{array}$ \\
\hline & 109 & H Woods \\
\hline & 109A & G Habib \\
\hline & 110 & LP Benson, Jr. \\
\hline & 110 & $\begin{array}{l}\text { R Welch } \\
R \text { Welch }\end{array}$ \\
\hline & $110 \mathrm{E}$ & $\begin{array}{l}\text { R Welch } \\
\text { L Hogans }\end{array}$ \\
\hline & $110 F$ & G Habib \\
\hline & $110 G$ & L Hogans \\
\hline & 111 & G Habib \\
\hline & 111A & $\begin{array}{l}\text { L Hogans } \\
\text { G Habib }\end{array}$ \\
\hline & 112 & P Diblasi \\
\hline & 112 & N Nesbitt \\
\hline & $112 \mathrm{M}$ & J Gurley \\
\hline & 114 & $\begin{array}{l}\text { R Welch } \\
\text { T Stephens }\end{array}$ \\
\hline & $114 \times x$ & M Smith \\
\hline & $115 \mathrm{~A}$ & PR Cameron \\
\hline & $115 \mathrm{~B}$ & PR Cameron \\
\hline & $115 \mathrm{C}$ & PR Cameron \\
\hline & 115D & PR Cameron \\
\hline & $115 \mathrm{E}$ & PR Cameron \\
\hline & $115 F$ & PR Cameron \\
\hline & $115 G$ & PR Cameron \\
\hline & $\begin{array}{l}115 \mathrm{H} \\
116\end{array}$ & $\begin{array}{l}\text { PR Cameron } \\
S \text { Brown }\end{array}$ \\
\hline & $116 x x$ & $\begin{array}{l}\text { S Brown } \\
\text { R Welch }\end{array}$ \\
\hline & 117 & W Powell \\
\hline & 119 & P Diblasi \\
\hline & 121 & $\begin{array}{l}\text { R Gmitter } \\
\text { M Stone }\end{array}$ \\
\hline & 122 & R Gmitter \\
\hline
\end{tabular}

Seation

Manufacturing BHESP

Eacilit 10 sea

Facilities \& so

Manufacturing

Manufacturing

- Manufacturing

EHESP

Faclifties seo

Manufacturing

Manufacturing

ecec

Computer Serv

Faailtios \& Sao

ocec

Manufacturing

Manufacturing

Manufacturing

Manufacturing

Manufacturing

Facilitios sea

Manufacturing

Engineering

Engineering

Engineering

Manufacturing

Manufacturing

Manufacturing

Manufacturing

Engineering

Manuforing

Manufacturing

Manufacturing

Manufacturing

Manufacturing

Manufacturing

Manufacturing

Manufacturing

Manufacturing

Facilities sec

Manufacturing

Manufacturing

Manufacturing

Manufacturing

Macc

Engineering

Engineering

Engineering

Engineering

Engineering

Englneering

Engineering

Englneering

Manufacturing

Manufacturing

Manufacturing

Faoilitieg Seo

Eacilities \& Sec

Facilities \& Sec

Eacllities \& Sec
Desaription

Produation Gas storage

Rad Pasto

Meah Room

Test Equipment Construction

officos

Machine Shop

Waste Management

offlces

Calibration/Maintenanoo

Ceramios

Incoming offices

MRP / SEC Room

Mech Equip

Incoming Inspoation

Recolving Traffio

Recelving

Tool Room

Officos

Tube Assembly

Fan Room (Tube procosaling)

Tubo Exhaust

Tubo exhauat, -.gas laboratory

Tube exhaust

Tube exhaust fixture loading - gas labor

Calibration/Vacouum

Magnetios Machining offices

Radiflo

Magnetias Test

OPTO ELECTRONIC ASSEMBLY

Produation stoak

React tve Metal a

Magnetios Winding Asm

Magnetias Winding Asm

Magnetias Transition

Magnetias Continuọa Fiow

Magnetias Transfer Presses

Magnetics Encapsulation

Breakroom

Generator Assembly

Offices

B stook

Final Inspection \& Certification,
Sholf Iffe

ShOCESS CAMERA

BLACK WHTE PRINTING

COLOR FIIM \& PAPER PROC

BLACK WHITE FILM PROC

SPRAY BOOTH

PHOTOGRAPHIC \& VIDEO STUDIO

SMALL PARTS STUDIO

PHOTOGRAPHY LABORATORY (ADMIN)

Capadtor

Production stock

Sub-assembly

Cafeteria

Security Bldg

Security Comm ctx (back up) 


\section{Owner}

NH Parsons

NH Parsons

H Parsons

R Bobbit

Carter

A Summerford

A Summerford

- George

TM Snowden, JIr.

H Foods

C Carter

N Stan

PR Cameron

$\checkmark$ Mocauley

$H$ Woods

I Miotko

M Tufarlello

H Woods

A Summerford

$K$ Hall

$v$ MeCauley

$K$ Hall

$J$ Neale

A Summerford

T Tomaro

T Tomaro

R Bobbitt

$R$ Weloh

- George

Towell

F Powell

พ Powell

A. Summerford

T Albaugh

T Albaugh

NE Demeza

A Summerford

$M$ Sinith

R Poterion

$\checkmark$ Harder

R Jones

M Chiarelli

R Bobbitt

R Welch

o Georgo

P Diblas

CR Hart

TM Snowden, Jr.

TM Snowden, Jr.

RJ Antepenko

RJ Anteponko

RJ Antepenko

RJ Antepenko

RJ Antepenko

NH Parsons

NH Parsons

NH Parsons

RJ Antepenko

\section{Seation}

Engineering

Engineering

Englneering

Manufacturing

Manufacturing

Facilitios i Soo

Facilities seo

Manufacturing

Engineering

Manufaoturing

Manufacturing

Manufacturing

Engineering

Programs

Manufacturing

Manufacturing

Facilities \& Sec

Manufacturing

Manufacturing

Faoilitios \& Seo

Faailities seo

Programs

Faoilities \& Soo

Programs

Faailities \& Seo

Manufacturing

Manufacturing

Manufacturing

Manufacturing

Manufacturing

Manufacturing

Manufacturing

Manufacturing

Manufacturing

Facilities \& Seo

Manufacturing

Manufacturing

Engineering

Facilities \& seo

QCec

EHCSP

Manufacturing

Computer serv

Computer serv

Manufaoturing

Manufacturing

Manufacturing

Facilities \& Seo

Engineering

Engineering

Engineering

Engineering

Engineering

Engineering

Engineering

Engineering

Engineering

Engineering

Engineering

Englneering

Engineering
Engineexing

\section{Description}

OA - CONTAMINATION CONTROI

CONTAMINATION CONTROL. LABORATORY

CONTAMINATION CONTROL STORAGE

Calibration/Maintenance

Callbration/Vaccuum

Fao. Maint. Shops

Fac. Maint. Officos

Genoral stook

OA - - ENGINEERING SUPPORI

Tube Processing

Callbration/Vacouum

Standards Lab

MAIL ROOM

Aation Center

Final Test

Product Tester support Lab

Computer Maintenanco

Final Test

Produat Tester Support storage

Fan Room (SECS)

Offices

offlces

Tolophon Switch Gear

offices

Electrical switoh Gear

Final Prop

Resin Casting/Vapor Blagt

Calibration/Maintenanos

Timer/Driver stookroom

Remote Receiving

Sub-assembly

Sub-assembly

Chemical Procesalng

Ean Room (Chem Clean)

Ceramics

Ceramics

OA -- MANUEACTURING INTEGRATION

Equipment

offices

Subseation offices

offices

Assombly Test

Calibration/Maintenance

A stook

General stook

BOC

MODEL SHOP, MILLING TURNING \& SAWING

FIIM DEPOSITION -- SPUTTERING EVAT.

TRANSDUCER - - ASM, DET TESTING

INCOMING TESTING/ATOMIC SPECTROSCOPY

SPECTROSCOPY

OPTICAI EMISSION

DARK ROOM

POLYMERS AND CHEMISTRY IAAB

GAS ILABORATORY

Spark SOUrCe M.S.

GAS LABORATORY SPECIAL TEST

GAS LABORATORY SAMPLE PREPARATION

ADVANCED ANALYSIS 


\section{Ownor}

RJ Antoponko

RJ Antepenko

RJ Antepenko

NH Parsons.

NH Parson

RJ Antepenko

RJ Anderson

RJ Antepenko

RJ Antepenko

RJ Antepenko

RJ Anteponko

RJ Antepenko

WE Swartz

WE Swartz

WE Swartz

WE Swartz

WE Swartz

WE Swartz

WE Swartz

WE Swartz

WE Swartz

WE Swartz

WE Swartz

WE Swartz

WE Swartz

TM Snowden, Jx.

TM Snowden, Jx.

SE Chapla

PR Cameron

R Littlo

$G$ Huffaker

P Valder

D Turner

PR Cameron

PR Cameron

SM Anderson

R Tuaker

TM Snowden, Jr.

TM Snowden, Jr.

TM Snowden, Jr.

NH Parsons

TM Snowden, Jx

CR Hart

FD Thibldea

PR Cameron

CR Hart

CR Hart

CR Hart

CR Hart

CR Hart

PR Krall

RJ Anderson

RJ Anderson
Enginooring

Enginoo

Enginooring

Engine

Engineering

Engineoring

Engineering

Enginoering

Engineering

Engineering

Engineering

Engineering

Engineering

Enginoering

Engineering

Englneering

Enginoering

Englnooring

Enginoring

Engineoring

Enginooring

Engineering

Englneering

Engineering

Engineering

Engineering

Engineering

Engineering

Engineering

Engineering

Engineering

Engineoring

Engineoring

Engineering

Englneering

Engineexing

Engineering

Manufacturing

Computer Serv

Computer Serv

Computer Sorv

Engineering

Engineering

Englneering

Human Resources

Englneering

Englneorting

Englnoering

Engineoring

Engineering

Engineering

Engineering

Engineering

Engineering

Engineering

Engineering

Engineering

Engineering

Engineering

Fngineoring

Engineering

Engineerin

Engineering
Desaription

OA - IABORATORY ORERATIONS

OA - IABORATORY OPERATTONS

OA - ILABORATORY OPERATIONS

AISLE "A"

AISLE "B"

AISLE "C"

AISLE "D"

AUGER ANALYSIS

AUGER ANALYSIS

$X$-RAY ANALYSIS

METALLURGY AND CERAMICS LIAB

MYDROGEN BRAZE, AIR FIRE, SPOTWELD

MATERIALS TESTING

SEM/TEY ANALYSIS

IMAGE ANALYSIS WITH OEFICES

SAMPLE PREPARATION

METAILOGRAPHY

platings and process laboratory

EURNACE

E-BEAM AND METATIIZE

PIASMA CLEAN

OA -- AND COMPUTER ROOM

LÄSER

CHEM. CLEAN TEST

BLAST

ASSEMBLY AREA

WELDING

GLASS

POLYMERS :AND RESINS

WINDING AND BONDING

CLOCK ASSEMBLY

VAULT ROOM -- HARDNESS/RESONATOR TEST

ENGINEERING CLASSIFIED COMPUTER ROOM

TECHNICAI PUBLICATIONS

Procurement

Sub-seation, seation offlces

Teohniques, user computing, networking a

Computer Security

REPROGRAPHICS

TECHNICAL COMMUNICATIONS SUPPORT

VAULT

PHOTOLITH, METALLIZATION PHOTORESTST

Large amall downflow, lab room halls:

ENVIRONMENTAL LAB

BLANK SHOP

LAC

NEUTRON DETECTOR

MAGNETICS

TECHNICAL INFO. CENTER (IIBRARY)

CAPACITOR CLEANING

PLASMA ARC SPRAY

GAS EILL AND ELEC. TEST

CAPACITOR DOWNELO

CAPACITOR EILL STATIONS

SUREACE MOUNT FACILITY

SCREEN PRINT -- UV CLEAN

SPECIAI TESTING 


\section{Owner}

RJ Anderson

RJ Anderson

RJ Anderson

RJ Anderson

RJ Anderson

EB Duokett, III

MA Merkel

EB Duckett, III

GE Gobbels

RJ Anderson

RJ Antepenko

RJ Antepenko

RJ Antepenko

RJ Antepenko

RJ Antepenko

RJ Antepenko

A summerford

D Turner

RD Walton

DE Patz

PR Cameron

TI Myriok

RA Fleming

RJ Anderson

RJ Anderson

RJ Anderson

GL Heim, Jr .

NE Demeza

JR Mikuliza

DJ Malbrough

WE Swartz

WE Swartz

WE Swartz

WE Swartz

WE Swartz

WE Swart

WE Swart:

WE swart

WE swartz

Twartz

WE Swartz

WE Swartz

EA Cote

EA Cote

DJ Malbrough

WE Swartz

WE Swartz

WE swart

WE swart

WE Swartz

WE Swartz

WE Swartz

WJ Malbrough

CG Wagner

CG Wagner

A Summerford

\section{Section}

Engineering Bngineering

Englneering

Engineoring

Engineering

Engineering

Engineering

Engineering

Engineering

Engineering

Engineering

Engineoring

Enginoering

Engineering

Engineering

Engineering

Engineering

Engineering

Facilities soo

Computer Serv

Enginoering

Enginooring

Engineoring

Engineering

Engineering

Engineering

Engineoring

Englneering

Englneering

Engineering

Engineering

Englineering

Engineering

Engineexing

Engineering

Engineering

Englneexing

Engineering

Engineering

Engineering

Engineoring

Engineoring

Engineering

Engineexing

Engineering

Engineering

Engineering

Engineering

Englneering

Engineering

Engineering

Englneering

Engineoring

Engineoring

Engineering

Englnooring

Engineering

Engineering

Engineering

Engineering

Engineering

Engineering

Engineering

Facilities s seo

\section{Doscription}

VACOUM EIRE

GYDROGEN EIRE \&' BRAZE, EVAP., O.V. CLEAN

PARTS ASM. \& INSE . HELDING

GYDROGEN FIRE BRAZE, PTS ASM. \& STORE

ELECTRONIC NEUTRON GENERATOR DEVELOPMENT

OA - GENERATOR ENGINEERING

ELECTRONIC GENERATOR DEV.

MECHANICAL PROCESSES

EBRROELECTRIC GENERATOR DEV.

Tube test

PHYSICAL/INCOMING TESTING

SPECIAL PROJECTS

GENERAI, ENCAPSULATION

FOAM BNCAPSULATION

INSTRUMENTATION

OA - POLYMER IAB

SHItch gear room

Data Procaasing

OA - BNGINEERING SUPPORT

DESIGN DEEINITION

OA - - ENGINEERING SUPPORT

ENGINEERING VAX COMPUTERS (UNCL)

ENGINEERING WORK STATIONS

OFFICE

STOCK ROOM

SHELE IIPE ROOM

CAD SYSTEM $\because$ 'MU,

Inspection

DEFECT ANALYSIS

DEFECT ANALYSIS

ALUMINA MACHINE SHO

POWDER PREP ROOM

PRESS ROOM

TAPE CASTING ROOMRAMICS IAB

FURNACE ROOM

SPRAY DRY ROOM

PZT MACHINE SHOP

HEADER BUILD ROOM

PARTICLE SIZE

Varlster Room Ceramios Lab

Injection Moulding Room

Metalize Room

Magnetios Winding

Field Test Magnetios Dev. Lab

Components Testing

Ultrasonios Laboratory

Ferroelectrio Rowder Laboratory

X-Ray Laboratory

Dark Room

Chem. Prep. Area

PT Test Room

Image Processing

Inspection and Computer Room

Components Testing

Powder Proc

Lamb Construation

Eguipment Room 
DJ Malbrough

E Rice

\section{RJ Siotke}

CG Wagner

A Summerford

CG Wagner

CG Wagner

CG Wagner

CG Wagner

C Carter

S Brown

S Brown

$S$ Brown

CG Wagner

S Brown

A Summerford

PR Krall.

CG Kagner

CG Wagner

W Ierna

CG Wagner

T Feikel

s Brown

N Stan

M Dopp

C Carter

A summerford

CG Wagner

CG Wagner

D Turner

AB Hammao, Jr.

A Summerford

$R$ Brown

DJ Malbrough

A Summerford

A summerford

$R$ Welch

$J$ Jefferson

A Summerford

RJ Anderson

DJ Malbrough

J Jefferson

$\checkmark$ Jefferson

\section{Bngineering} Fadilties c Sec Manufacturing

Engineering

Manufacturing

Enginooring

Englneoring

Faollities \& Seo

Englneering

Facilitios Seo

Englineering

Engineering

Engineering

Manufacturing

Manufacturing

Manufacturing

Manufacturing

Engineering

Manufacturing

Manufacturing

Facilitios soo

Engineering

Enginoering

Engineoring

QCiC

Engineering

Faoliltios soo

Manufacturing

Manufacturing

Manufacturing

Manufaoturing

Manufacturing

Manufacturing

Manufacturing

Englneering.

Engineering

Computer Serv

Faoilities \& Seo

Englneering

Faallities \& soc

Manufacturing

Engineering

Faallitios soo

Eacilities \& Seo

Manufacturing

EH\& SP

Facilities seo

Enginoering

Engineering

EHESP

EHESP
Mech Room

Environmental condition f Test

SE3150 Eng. Fast Rise Tester

Product Tester Support

Power Sources Support/ Thermal Battery

Thermal Battery Eabrication

Mech Room

OA.-- Engineering Support

Noch Room

Tost Area

OA - Engineer

Calibration/Vacouum

Heather Iathe Room

Heather Clean Room

EB pold

Heather Tost Inspeotion

Produation shipping

utility

Opto Development

Battery Davelopment

Battery Development

NDD Quality Control \& Prod Aac.

Battery Production Dryroom

Breakroom

Instrumentation

LAMB

Standards Iab

Clock Resonator

Callbration/Vacouum

Callbration/Vacauum

Moch Room

Iron Disulfide Rrocessing

Machine Shop

AMSL Room

OA -- ENGINEERING SUPBORT

Meoh Equip

RTG (plan shut down 12/90)

RTG Failure Analysis

vtilities Operations

Waste Neutralization

Chemiaal storage

Fire station

Plant Grounds Bldg

Tube Test

Acoelerator Lab

Fire Tralning Bld

Hose storage Facility 



\section{CONDUCT OF OPERATIONS \\ ORGANIZATION AND TASK BREAKDOWN}

\section{CoOp COMMITTEE}

Ovarall management and imṕlementation of $\mathrm{CoO}$ by 7/9/90.

Continually assess businese impact/benefit.

Consolidate implementation plans/schedules.

Each member to laad a sub-team.

Ensure plantwide training:

\begin{tabular}{|c|c|c|c|c|}
\hline $\begin{array}{l}\text { AREA DEFINITION } \\
\text { TEAM }\end{array}$ & $\begin{array}{l}\text { PLANTWIDE GUIDELINE } \\
\text { TEAM }\end{array}$ & $\begin{array}{l}\text { HIGH/MODERATE } \\
\text { RISK AREA TEAM }\end{array}$ & $\begin{array}{l}\text { LOW RISK AREA } \\
\text { TEAM }\end{array}$ & $\begin{array}{l}\text { ALL OTHER AREA } \\
\text { TEAM }\end{array}$ \\
\hline $\begin{array}{l}\text { Reviow/update existing area } \\
\text { map. }\end{array}$ & $\begin{array}{l}\text { Ro-ovaluete } 18 \text { guidelines for } \\
\text { plantwide applicability. }\end{array}$ & $\begin{array}{l}\text { Reviow quidelinos for area } \\
\text { applicability. }\end{array}$ & $\begin{array}{l}\text { Roviow guidalines for area } \\
\text { applicabllity. }\end{array}$ & $\begin{array}{l}\text { Reviow quidelines for area } \\
\text { applicability. }\end{array}$ \\
\hline $\begin{array}{l}\text { Idenitify owners for each } \\
\text { area. }\end{array}$ & $\begin{array}{l}\text { Evaluato oxioting lovol of } \\
\text { compliance. }\end{array}$ & $\begin{array}{l}\text { Assess current lovel of } \\
\text { compliance. }\end{array}$ & $\begin{array}{l}\text { Assess current lovel of } \\
\text { complianco. }\end{array}$ & $\begin{array}{l}\text { Assess current lovel of } \\
\text { compliance. }\end{array}$ \\
\hline
\end{tabular}

Divido areas into cato- Dovelop implementation plans/

gories:

high/moderate risk

low risk

all other

schedules for each.

Uso sub-toams if noeded.

Assure appropriate documentation.

Recommond surveillance roquirements. Assure appropriate docDEFINITION TEAMS.

\section{REGROUP WITH CORE TO IDENTIFY OVERLAPS AND ESTABLISH GUIDELINE DEVELOPMENT/}

umentation.

Dovalop implementation plans and sohedules for total area compliance. $\begin{array}{ll}\text { Davelop implementation plans } & \text { Devolop implementation plans } \\ \text { and sohedules for total area } & \text { and schedules for total areas }\end{array}$ complianco.

\section{GUIDELINE DEVELOPMENT/DEFINITION TEAMS}

Establish policies/procedures for one specific criteria.

Provide area teams with documents for use in implementation.

Recommend surveillance requirements. 



\section{AREA CATEGORY COMPLIANCE MATRIX}

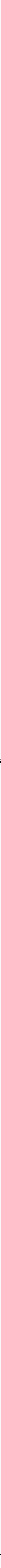




\section{AREA CATEGORY COMPLIANCE MATRIX}

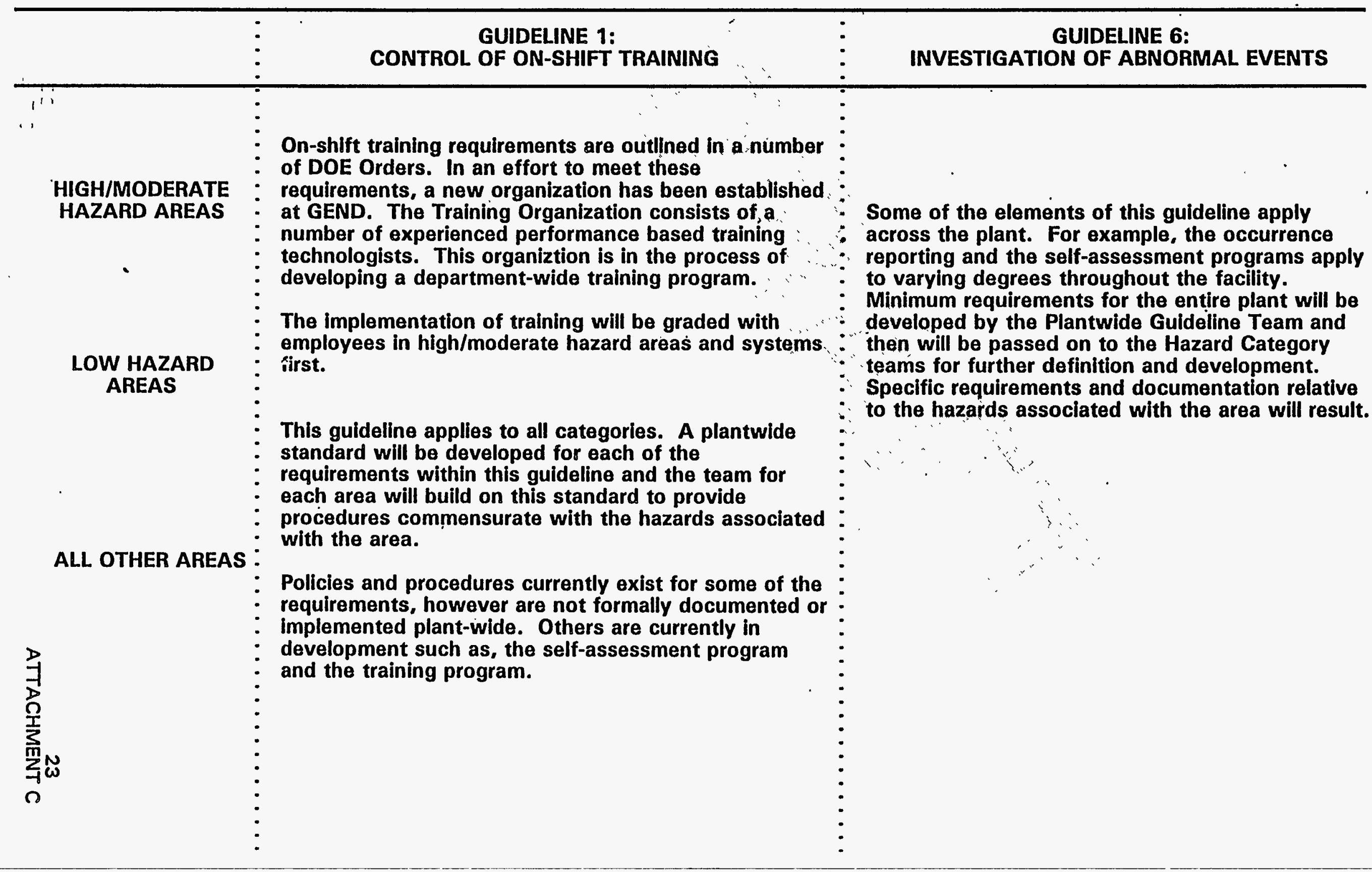




\section{AREA CATEGORY COMPLIANCE MATRIX}

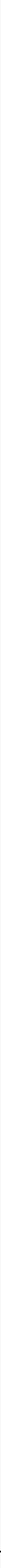




\section{AREA CATEGORY COMPLIANCE MATRIX}

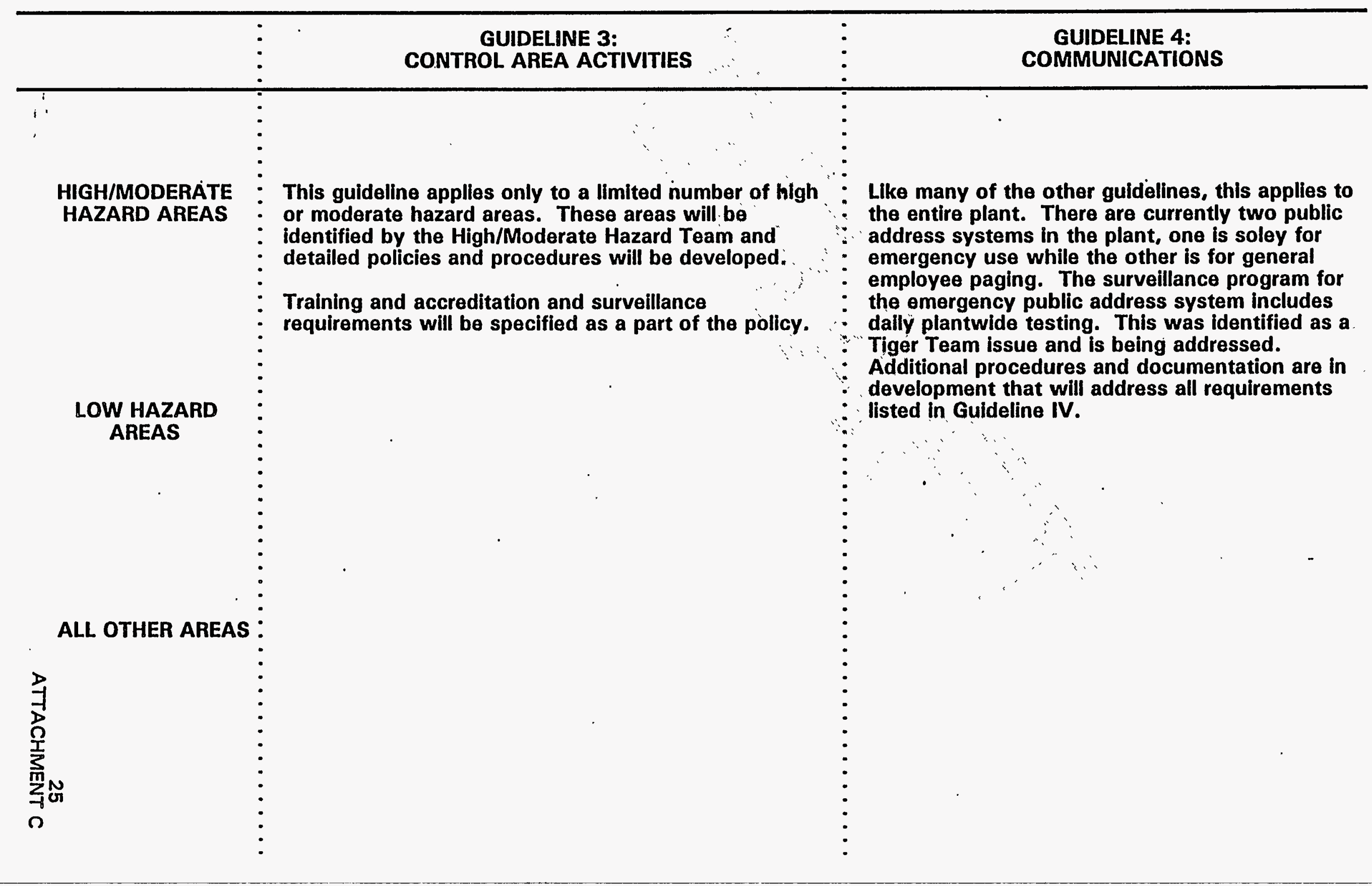




\section{AREA CATEGORY COMPLIANCE MATRIX}

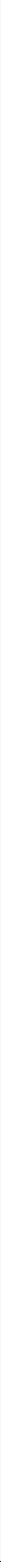




\section{AREA CATEGORY COMPLIANCE MATRIX}

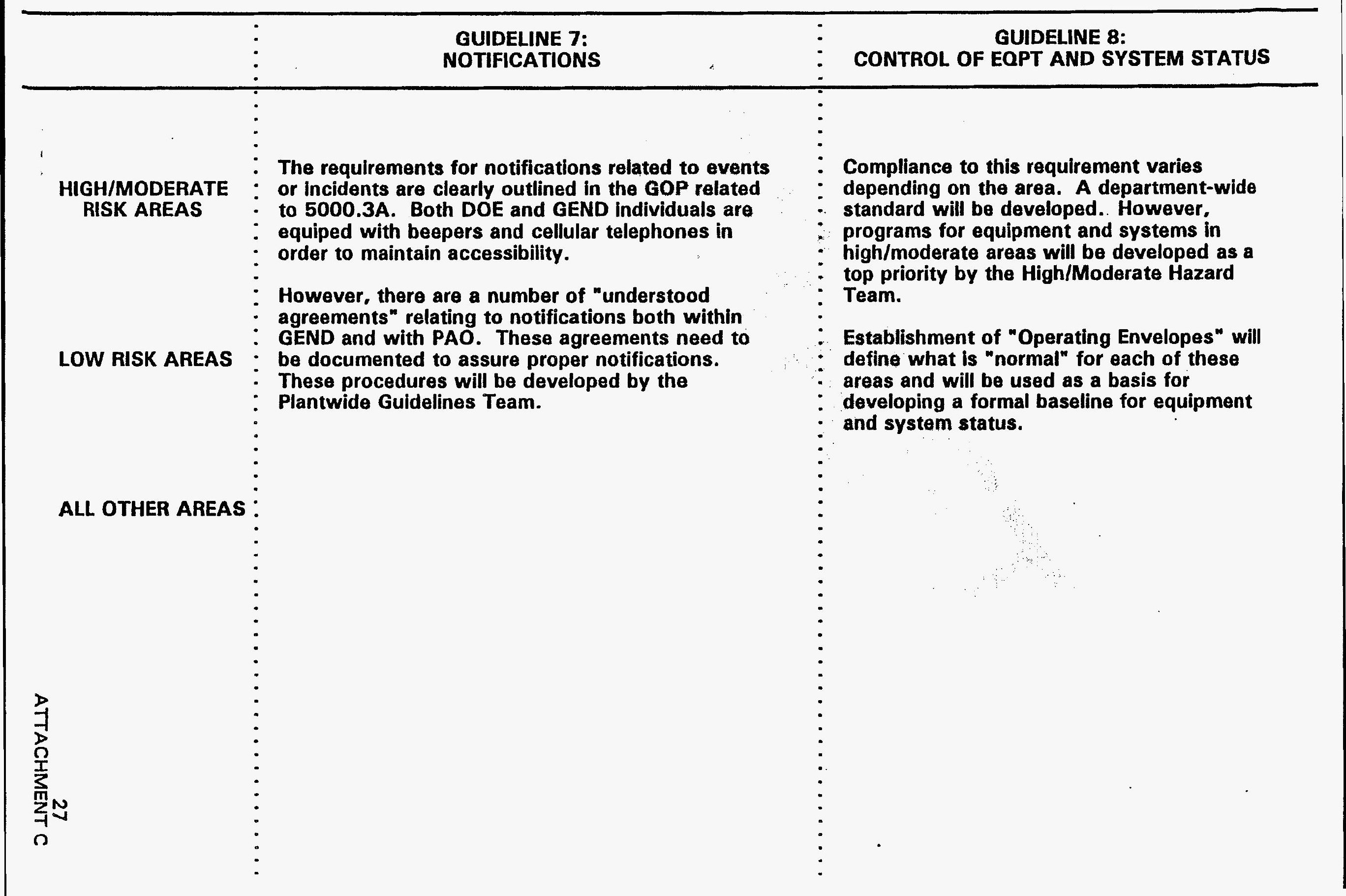




\section{AREA CATEGORY COMPLIANCE MATRIX}

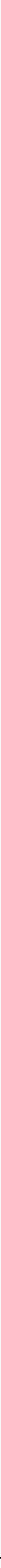




\section{AREA CATEGORY COMPLIANCE MATRIX}

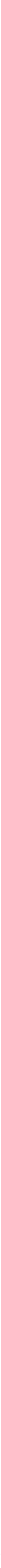




\section{AREA CATEGORY COMPLIANCE MATRIX}

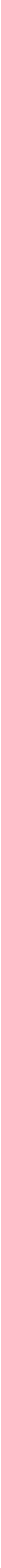




\section{AREA CATEGORY COMPLIANCE MATRIX}

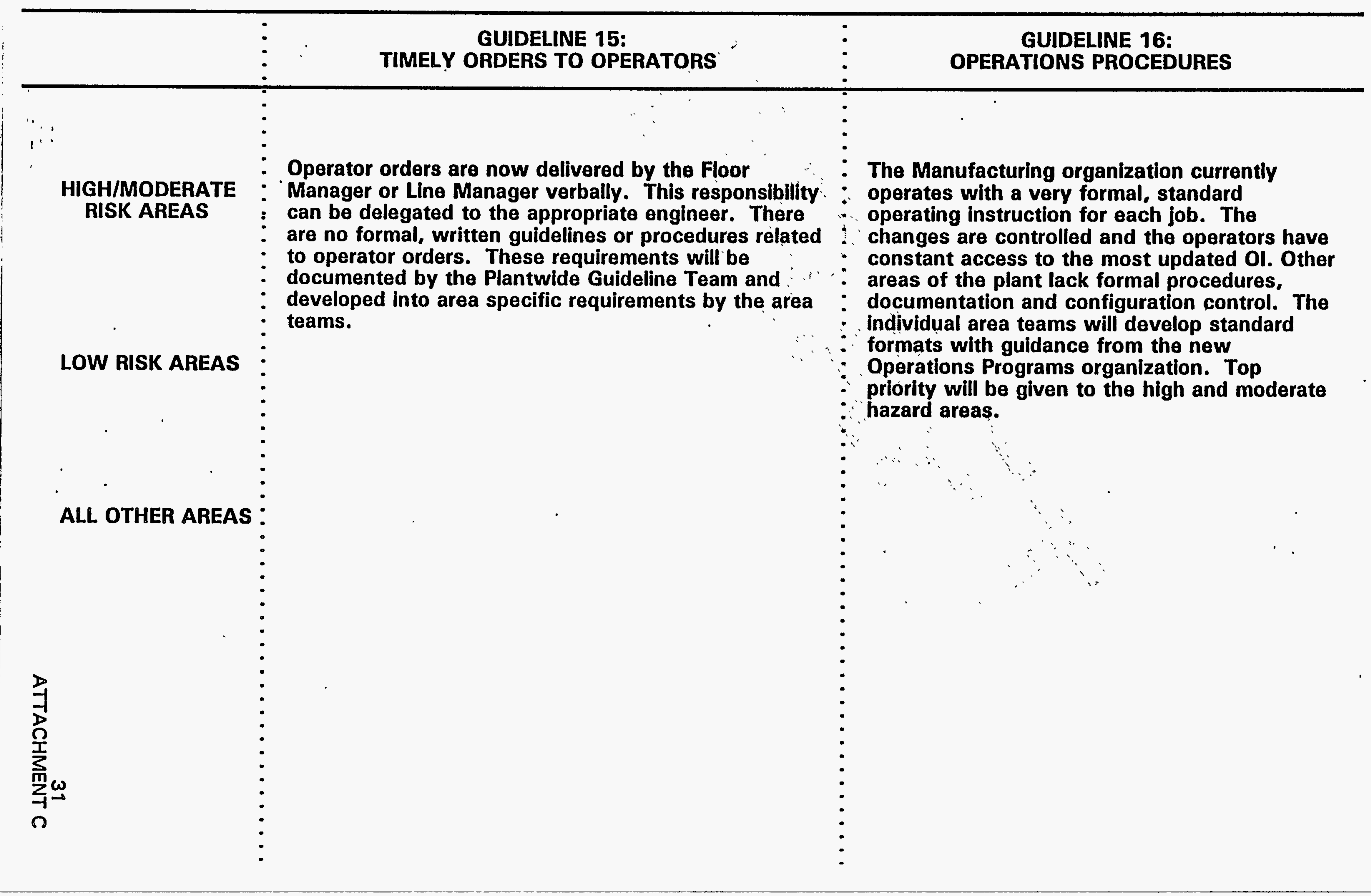




\section{AREA CATEGORY COMPLIANCE MATRIX}

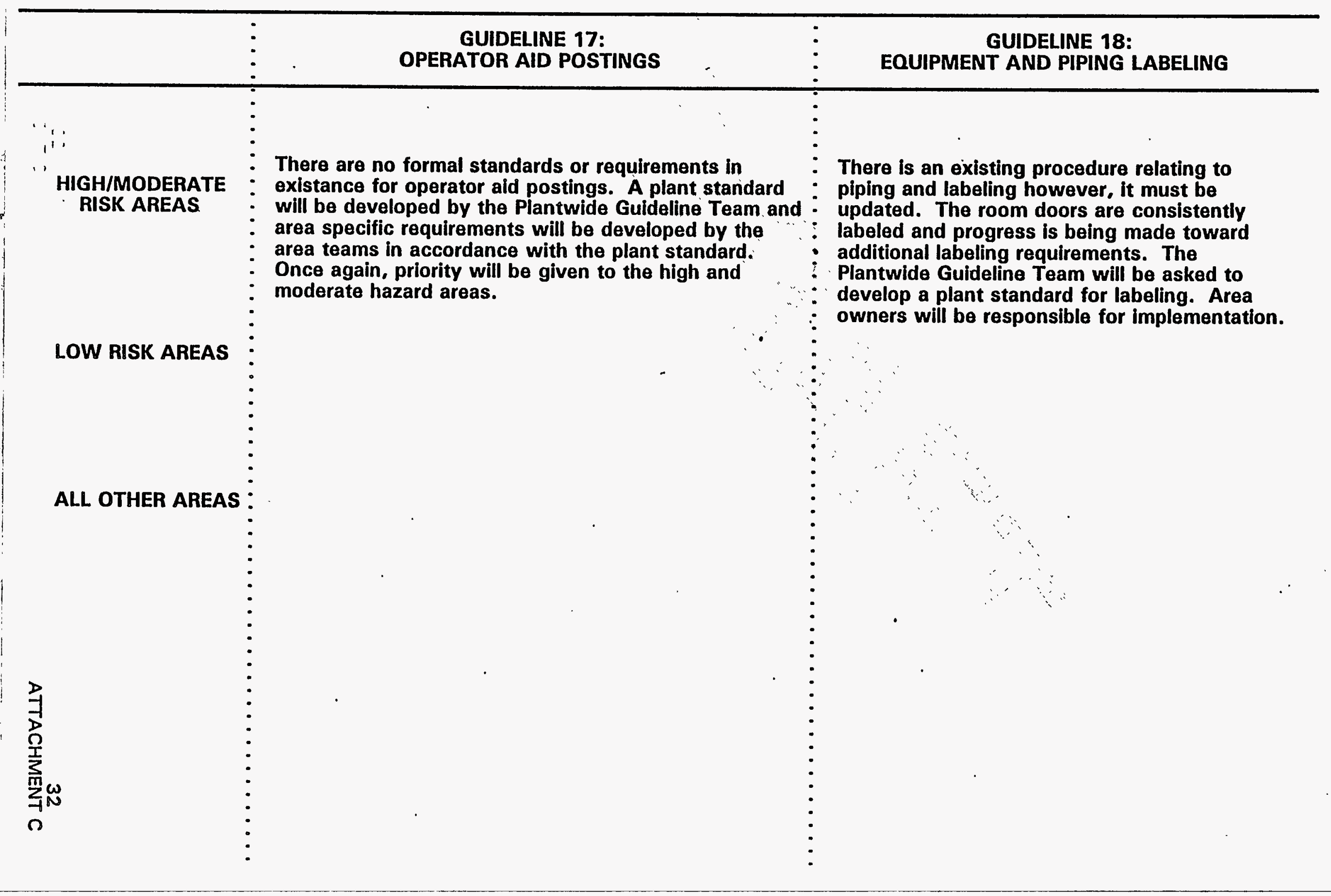





\section{PINELLAS PLANT

\section{Conduct Operations Compliance by Area}

Name of Area

ENGINEERING

1. Components Testing

2. Gen. \& Det. Development

3. Neutron Tube Development

4. Polymers \& Chemistry Lab

\begin{tabular}{|l|l|l|l|l|l|l|l|l|l|l|l|l|l|l|l|l|l|}
\hline 1 & 2 & 3 & 4 & 5 & 6 & 7 & 8 & 9 & 10 & 11 & 12 & 13 & 14 & 15 & 16 & 17 & 18 \\
\hline
\end{tabular}

\begin{tabular}{|l|l|l|l|l|l|l|l|l|}
\hline & 3 & 1 & 3 & 3 & 3 & 3 & 3 & 3 \\
\hline
\end{tabular}

3.

\begin{tabular}{|l|l|l|l|l|l|l|l|l|l}
3 & 3 & 1 & 3 & 3 & 3 & 3 & 3 & 3 & 3
\end{tabular}

\begin{tabular}{llllll|l|l|l}
3 & 3 & 3 & 3 & 2 & 3 & 3 & 3
\end{tabular}

\begin{tabular}{|l|l|l|l|l|l|}
3 & 3 & 1 & 3 & 3 & 3 \\
\hline
\end{tabular}

\begin{tabular}{l|l|l} 
& & \\
\hline & 3 & 3
\end{tabular}

\begin{tabular}{l|l|l} 
& & \\
\hline & 3 & 3
\end{tabular}

\begin{tabular}{ll|l}
3 & 3 \\
\hline & 3
\end{tabular}

\begin{tabular}{|c|c|c|c|c|}
\hline 3 & 3 & 1 & & 3 \\
\hline
\end{tabular}

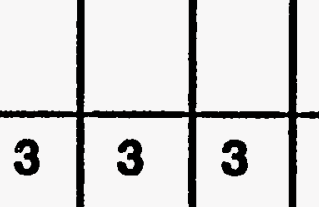

\begin{tabular}{llll|l} 
& & & & \\
\hline & 3 & 3 & 1 & 3 \\
& & & & \\
\end{tabular}

\begin{tabular}{l|l|l|l|} 
& & & \\
\hline 3 & 3 & 3 & 3
\end{tabular}

\begin{tabular}{|l|l|l|l|l|l|l|}
\hline 3 & 3 & 3 & 2 & 3 & 3 & 3 \\
\hline
\end{tabular}

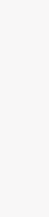

5. Precision Electronic Comp

\begin{tabular}{|l|l|l|l|l|l|l|l|l|l|l|l|l|l|}
3 & 3 & 3 & 3 & 3 & 3 & 3 & 3 & 3 & 3 & 2 & 3 & 3 & 3 \\
\hline
\end{tabular}

$$
\text { - } \hat{-1}
$$




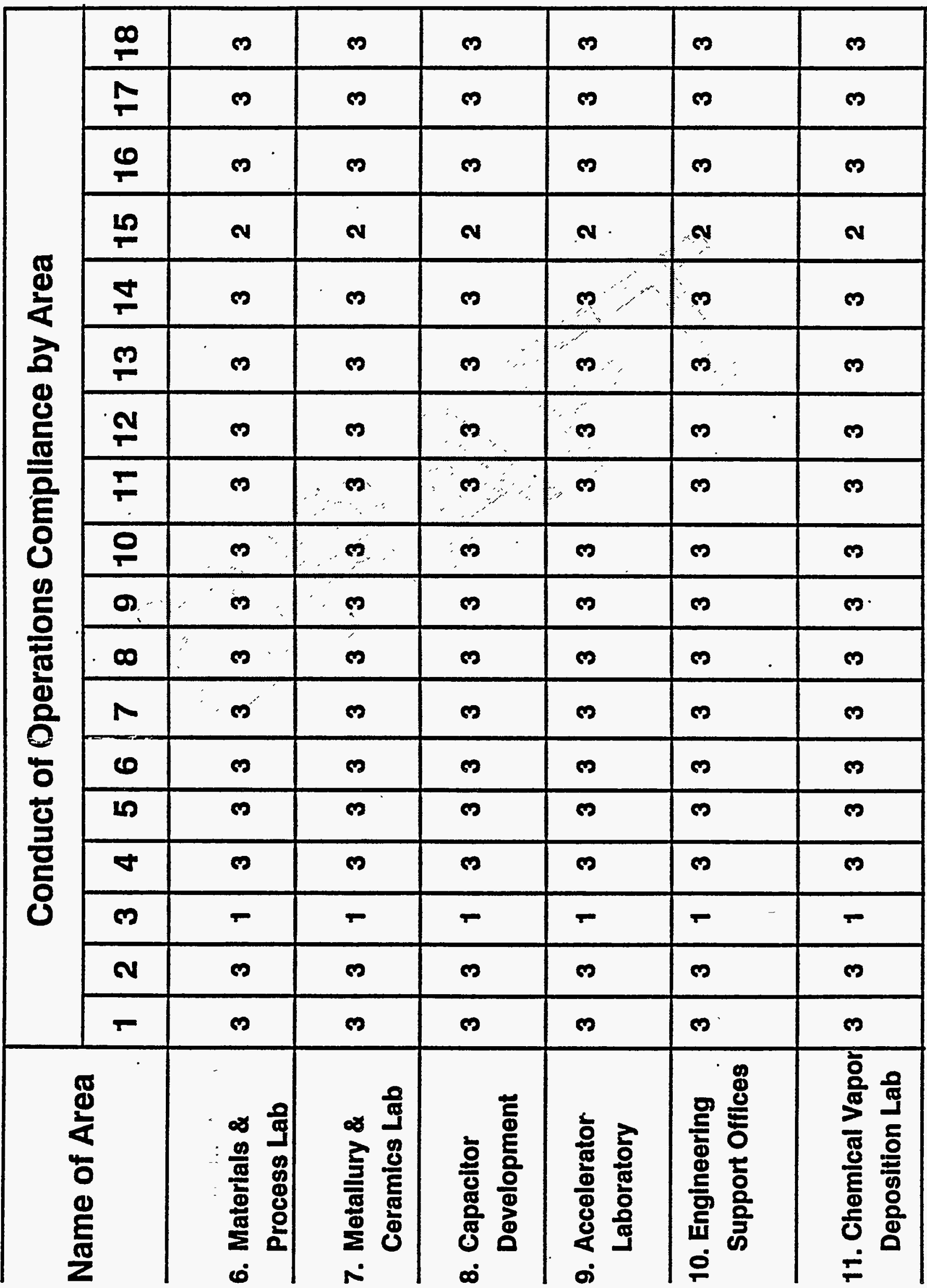




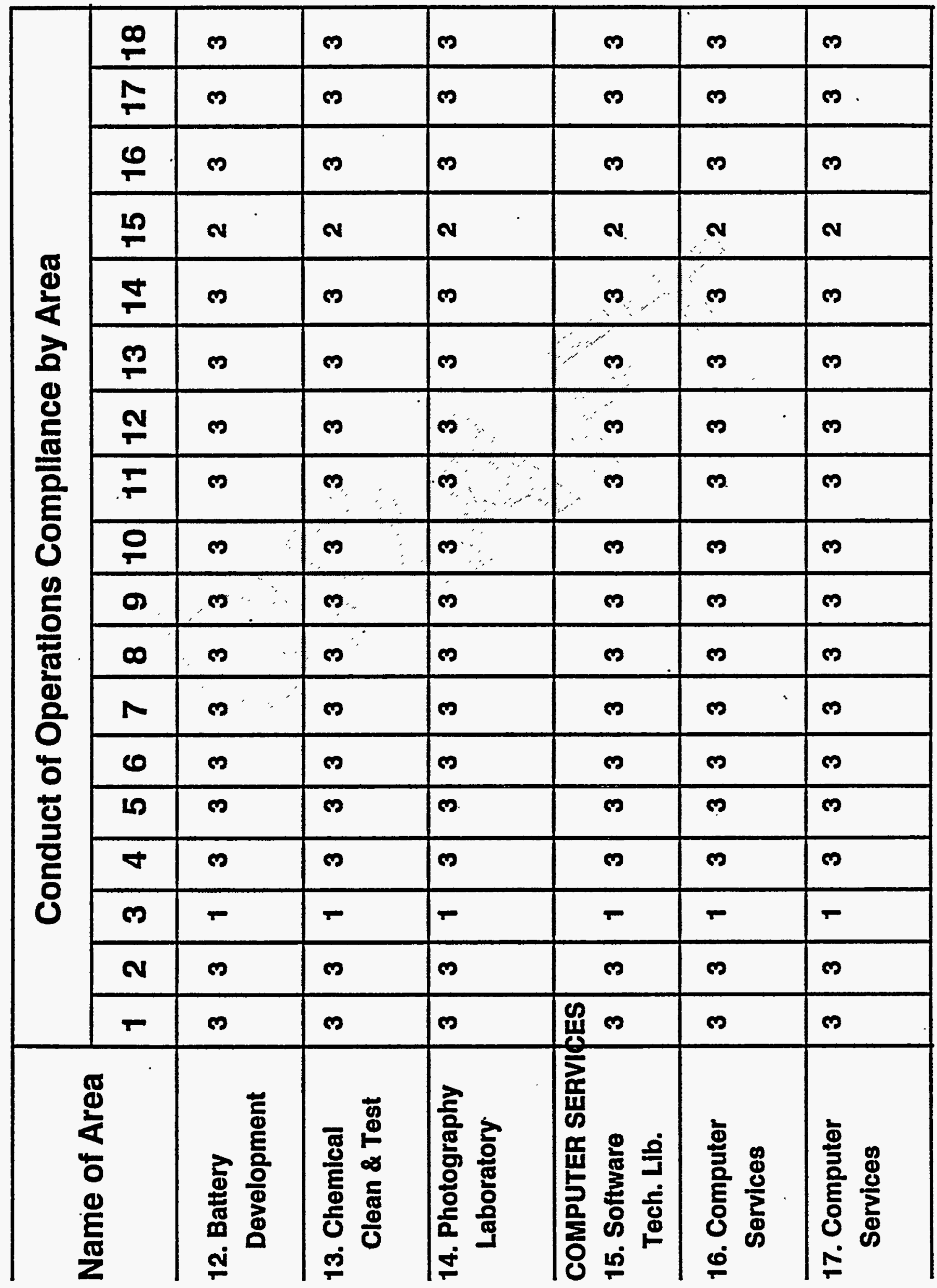




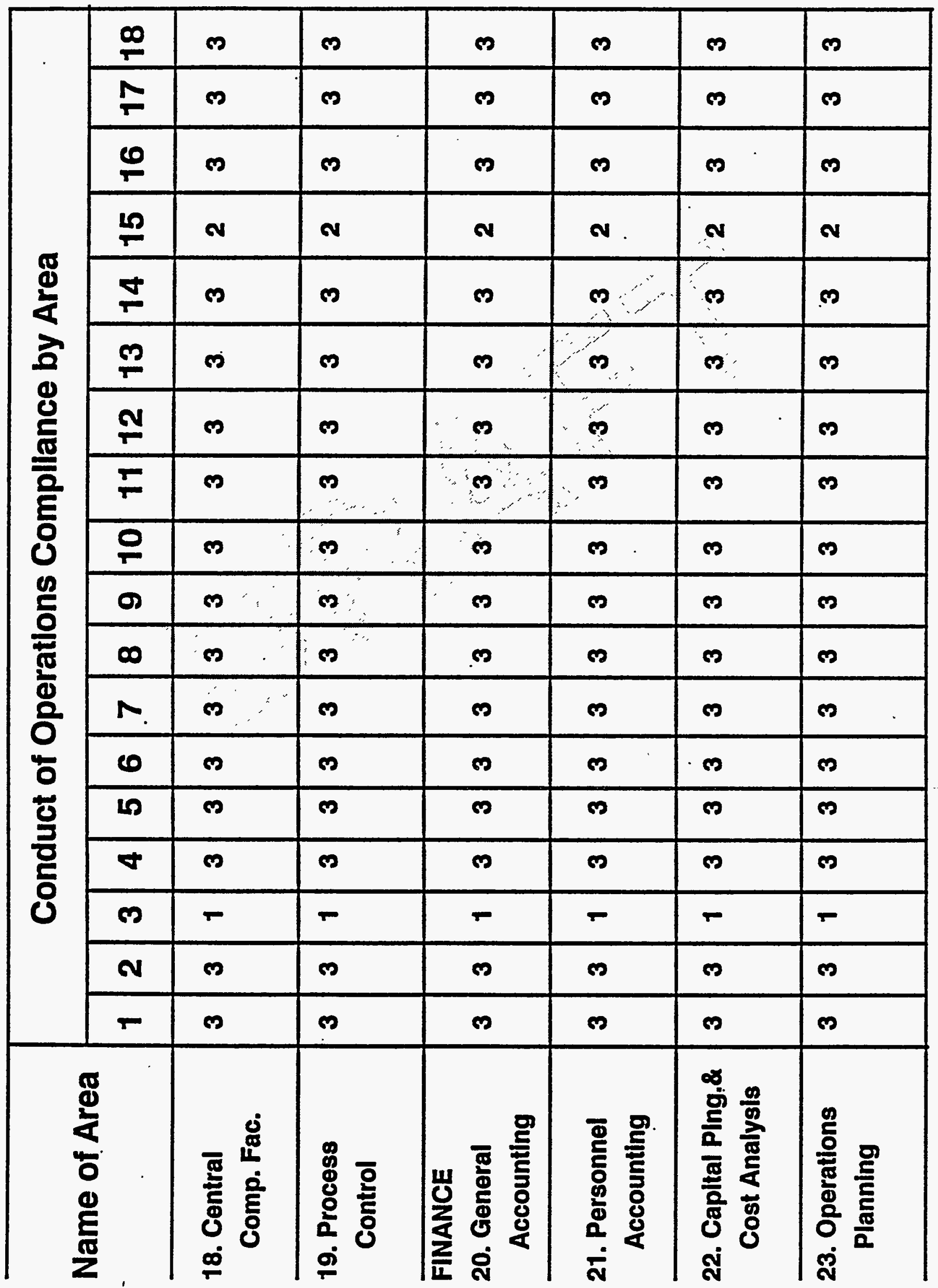




\begin{tabular}{|c|c|c|c|c|c|c|c|}
\hline & $\underset{\boldsymbol{\infty}}{\boldsymbol{\infty}}$ & $\boldsymbol{\infty}$ & $\infty$ & $\boldsymbol{O}$ & $\boldsymbol{\infty}$ & & $\infty$ \\
\hline & 10 & $\infty$ & $\boldsymbol{\infty}$ & $\infty$ & $\infty$ & & $\infty$ \\
\hline & 5 & $\boldsymbol{\infty}$ & P & $\infty$ & $\boldsymbol{\infty}$ & & $\infty$ \\
\hline & م & $\boldsymbol{N}$ & $\mathbf{N}$ & $\boldsymbol{N}$ & $\mathbf{v}$ & & $\mathbf{N}$ \\
\hline & & $\infty$ & $\infty$ & $\infty$ & $\infty$ & & $\infty$ \\
\hline & $\infty$ & क & $\infty$ & $\infty$ & $\infty$ & & $\infty$ \\
\hline & $\boldsymbol{N}$ & $\infty$ & $\infty$ & $\infty$ & $\infty$ & & $\boldsymbol{\infty}$ \\
\hline & 7 & $\infty$ & $\infty$ & 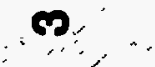 & $\infty$ & & $\infty$ \\
\hline 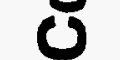 & 0 & $\infty$ & $\because \infty$ & $\infty$ & $\infty$ & & $\boldsymbol{\infty}$ \\
\hline & $\boldsymbol{O}$ & $\infty$ & $\boldsymbol{\infty}$ & $\leftrightarrow$ & $\infty$ & & ( \\
\hline & $\boldsymbol{\infty}$ & $\boldsymbol{m}$ & $\infty$ & $\infty$ & $\infty$ & & $m$ \\
\hline & $N$ & $\boldsymbol{\infty}$ & $\boldsymbol{\infty}$ & $\infty$ & ? & & $\infty$ \\
\hline & 10 & $\infty$ & $\infty$ & $\infty$ & $\infty$ & & $\boldsymbol{\varphi}$ \\
\hline & ס & $\infty$ & $\infty$ & 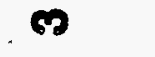 & $\boldsymbol{\infty}$ & & $\boldsymbol{\infty}$ \\
\hline & $\boldsymbol{\nabla}$ & $\boldsymbol{\infty}$ & $\infty$ & $\infty$ & $\infty$ & & $\boldsymbol{\infty}$ \\
\hline 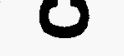 & 9 & $r$ & $F$ & $r$ & $r$ & & $F$ \\
\hline & $\mathbf{N}$ & $\infty$ & $\boldsymbol{\infty}$ & $\infty$ & $\infty$ & & $\infty$ \\
\hline & $r$ & $\boldsymbol{\infty}$ & P & $\boldsymbol{O}$ & $\infty$ & & $m$ \\
\hline & & 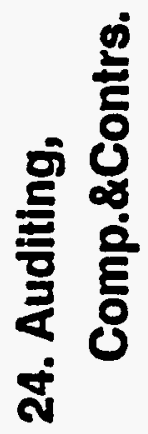 & 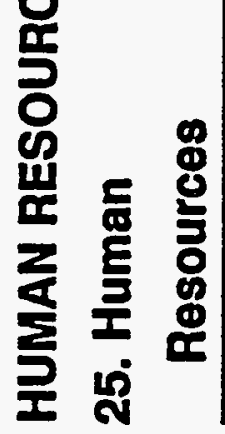 & 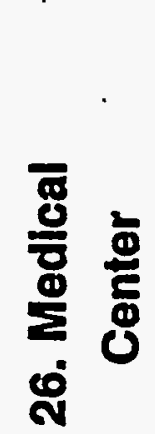 & 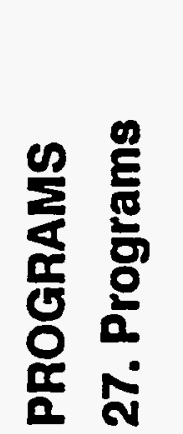 & 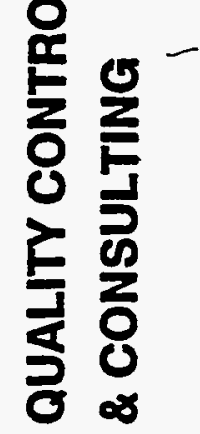 & 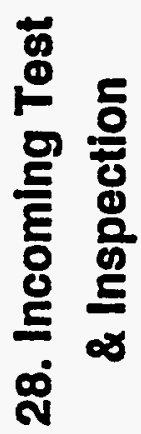 \\
\hline
\end{tabular}




\begin{tabular}{|c|c|c|c|c|c|c|c|c|c|c|c|c|c|c|c|c|c|c|}
\hline \multirow{2}{*}{ Name of Area } & \multicolumn{18}{|c|}{ Conduct of Operations Compllance by Area } \\
\hline & 1 & 2 & 3 & 4 & 5 & 6 & 7 & 8 & 9 & 10 & 11 & 12 & 13 & 14 & 15 & 16 & 17 & 18 \\
\hline $\begin{array}{l}\text { 29. Purchased } \\
\text { Material Qual. }\end{array}$ & 3 & 3 & 1 & 3 & 3 & 3 & 3 & 3 & 3 & 3 & 3 & 3 & 3 & 3 & 2 & 3 & 3 & 3 \\
\hline $\begin{array}{l}\text { 30. QC Computer } \\
\text { Room }\end{array}$ & 3 & 3 & 1 & 3 & 3 & 3 & 3 & 3 & 3 & 3 & 3 & 3 & 3 & 3 & 2 & 3 & 3 & 3 \\
\hline $\begin{array}{l}\text { 31. General Offlce } \\
\text { Area }\end{array}$ & 3 & 3 & 1 & 3 & 3 & 3 & 3 & 3 & 3 & 3 & 3 & 3 & 3 & 3 & 2 & 3 & 3 & 3 \\
\hline $\begin{array}{l}\text { 32. QC Product } \\
\text { Acceptance }\end{array}$ & 3 & 3 & 1 & 3 & 3 & 3 & 3 & 3 & 3 & 3 & 3 & 3 & 3 & 3 & 2 & 3 & 3 & 3 \\
\hline $\begin{array}{l}\text { 33. Shelf Life } \\
\text { Room }\end{array}$ & 3 & 3 & 1 & 3 & 3 & 3 & 3 & 3 & 3 & 3 & 3 & 3 & 3 & 3 & 2 & 3 & 3 & 3 \\
\hline $\begin{array}{l}\text { MANUFACTURING } \\
\text { 34. Tube Sub- } \\
\text { Assembly }\end{array}$ & 3 & 3 & 1 & 3 & 3 & 3 & 3 & 3 & 3 & 3 & 3 & 3 & 3 & 3 & 2 & 3 & 3 & 3 \\
\hline
\end{tabular}




\begin{tabular}{|c|c|c|c|c|c|c|c|c|c|c|c|c|c|c|c|c|c|c|}
\hline \multirow{2}{*}{ Name of Area } & \multicolumn{18}{|c|}{ Conduct of Operations Compllance by Area } \\
\hline & 1 & 2 & 3 & 4 & 5 & 6 & 7 & 8 & 9 & 10 & 11 & 12 & 13 & 14 & 15 & 16 & 17 & 18 \\
\hline $\begin{array}{l}\text { 35. Tube } \\
\text { Assembly \& Test }\end{array}$ & 3 & 3 & 1 & 3 & 3 & 3 & 3 & 3 & 3 & 3 & 3 & 3 & 3 & 3 & 2 & 3 & 3 & 3 \\
\hline $\begin{array}{l}\text { 36. Generator } \\
\text { Assembly }\end{array}$ & 3 & 3 & 1 & 3 & 3 & 3 & 3 & 3 & 3 & 3 & 3 & 3 & 3 & 3 & 2 & 3 & 3 & 3 \\
\hline $\begin{array}{l}\text { 37. Resin Casting \& } \\
\text { Final Unit Prep }\end{array}$ & 3 & 3 & 1 & 3 & 3 & 3 & 3 & 3 & 3 & 3 & 3 & 3 & 3 & 3 & 2 & 3 & 3 & 3 \\
\hline $\begin{array}{l}\text { 38. Parts } \\
\text { Fabrication }\end{array}$ & 3 & 3 & 1 & 3 & 3 & 3 & 3 & 3 & 3 & 3 & 3 & 3 & 3 & 3 & $?$ & 3 & 3 & 3 \\
\hline $\begin{array}{l}\text { 39. Ceramics } \\
\text { Shop }\end{array}$ & 3 & 3 & 1 & 3 & 3 & 3 & 3 & 3 & 3 & 3 & 3 & 3 & 3 & 3 & 2 & 3 & 3 & 3 \\
\hline 40. RTG & 3 & 3 & 1 & 3 & 3 & 3 & 3 & 3 & 3 & 3 & 3 & 3 & 3 & 3 & 2 & 3 & 3 & 3 \\
\hline
\end{tabular}




\begin{tabular}{|c|c|c|c|c|c|c|c|}
\hline & $\infty$ & $\boldsymbol{\infty}$ & $\infty$ & $\infty$ & $\infty$ & $\infty$ & $\boldsymbol{\infty}$ \\
\hline & $m$ & $\infty$ & $\infty$ & $\infty$ & $\infty$ & $\infty$ & $\infty$ \\
\hline & 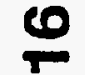 & $\infty$ & $\infty$ & $\boldsymbol{\infty}$ & $\infty$ & $\boldsymbol{\infty}$ & $\infty$ \\
\hline & 10 & $\mathbf{N}$ & $\boldsymbol{N}$ & $\boldsymbol{N}$ & $\boldsymbol{N}$ & $\mathbf{N}$ & $\boldsymbol{N}$ \\
\hline & & $\infty$ & $\infty$ & $\infty$ & $\boldsymbol{m}^{\prime}$ & $\infty$ & $\infty$ \\
\hline & 4 & $\infty$ & $\infty$ & $\infty$ & $\infty$ & $\infty$ & $\boldsymbol{\infty}$ \\
\hline & $\mathbf{N}$ & $\infty$ & $\infty$ & $\infty$ & $\infty$ & $\infty$. & $\boldsymbol{\infty}$ \\
\hline & $m$ & $\infty$ & $\infty$ & $\dot{\boldsymbol{p}}$ & $\infty$ & $\infty$ & $\infty$ \\
\hline 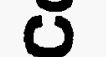 & 0 & $\infty$ & $\infty$ & $\infty$ & $\boldsymbol{\infty}$ & $\boldsymbol{m}$ & $\infty$ \\
\hline & O & $\infty$ & $\infty$ & $\infty$ & $\infty$ & $\infty$ & $\infty$ \\
\hline & $\infty$ & $\infty$ & $\boldsymbol{\infty}$ & $\infty$ & $\boldsymbol{\infty}$ & $\infty$ & $\infty$ \\
\hline & $N$ & $\infty$ & $\infty$ & $\infty$ & $\infty$ & $\infty$ & $\boldsymbol{\infty}$ \\
\hline & 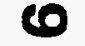 & $\infty$ & $\infty$ & $\boldsymbol{C O}$ & $\boldsymbol{\infty}$ & $\infty$ & $\infty$ \\
\hline 0 & 19 & $\boldsymbol{D}$ & $\infty$ & $\infty$ & $\infty$ & $\infty$ & $\infty$ \\
\hline & $\nabla$ & $\infty$ & $\boldsymbol{\infty}$ & $\infty$ & $\infty$ & $\infty$ & $\infty$ \\
\hline 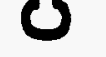 & $\infty$ & $r$ & $F$ & 7 & $F$ & $\Gamma$ & $r$ \\
\hline & $\mathbf{N}$ & $\infty$ & $\infty$ & $\boldsymbol{\infty}$ & $\infty$ & $\boldsymbol{0}$ & $\boldsymbol{\infty}$ \\
\hline & $T$ & $\infty$ & $\infty$ & $\boldsymbol{\infty}$ & $\infty$ & $\infty$ & $\infty$ \\
\hline & & $\begin{array}{l}\frac{8}{8} \\
\frac{0}{8} \\
\frac{5}{0} \\
\frac{8}{5} \\
\frac{8}{8}\end{array}$ & 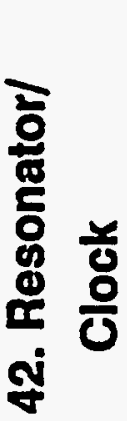 & 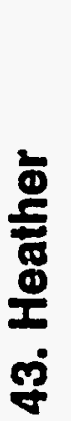 & $\frac{3}{8}$ & $\begin{array}{l}\frac{0}{3} \\
\frac{9}{0} \\
\frac{8}{8} \\
\frac{0}{80} \\
10\end{array}$ & $\sum_{0}^{\infty}$ \\
\hline
\end{tabular}




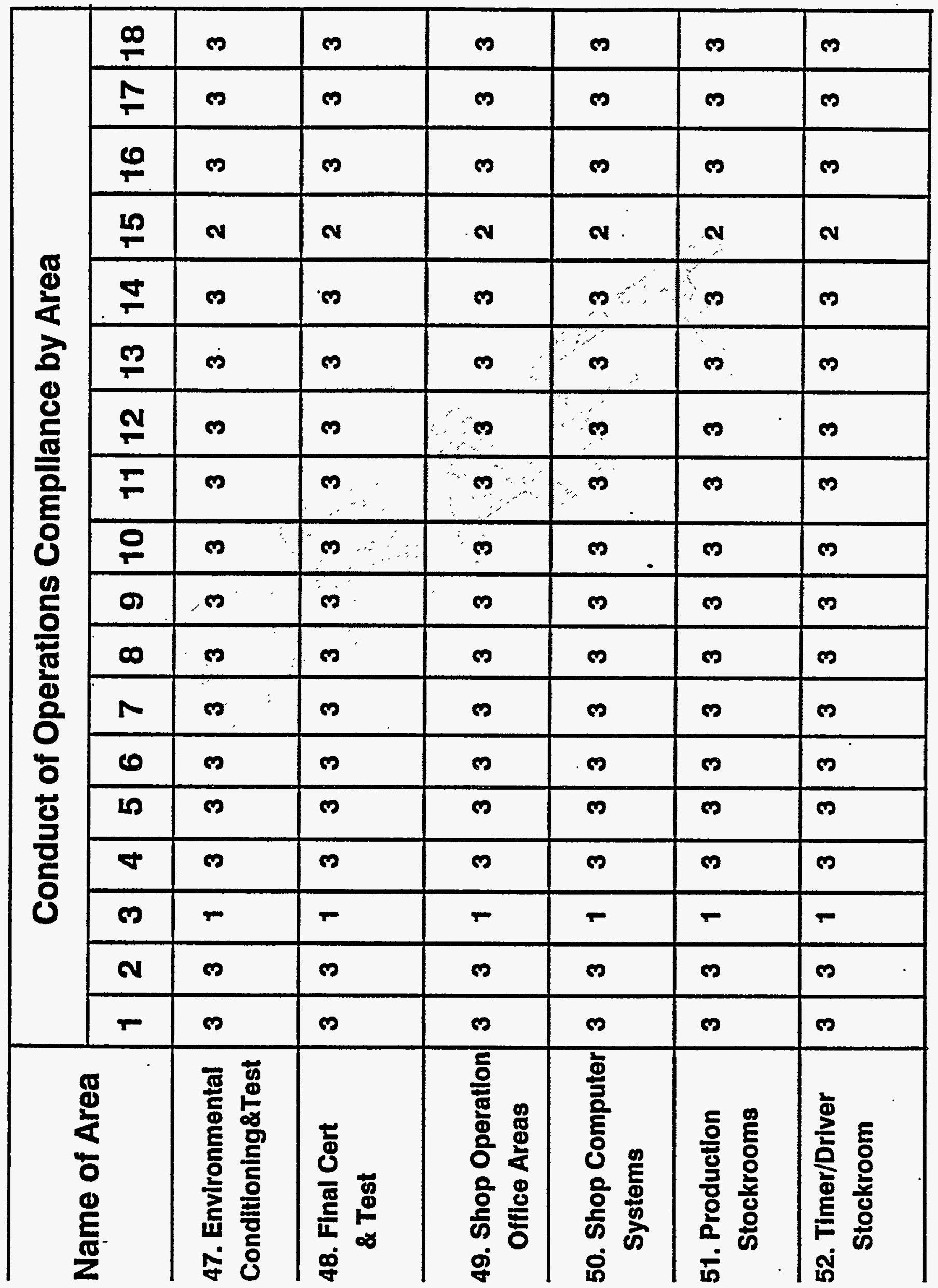




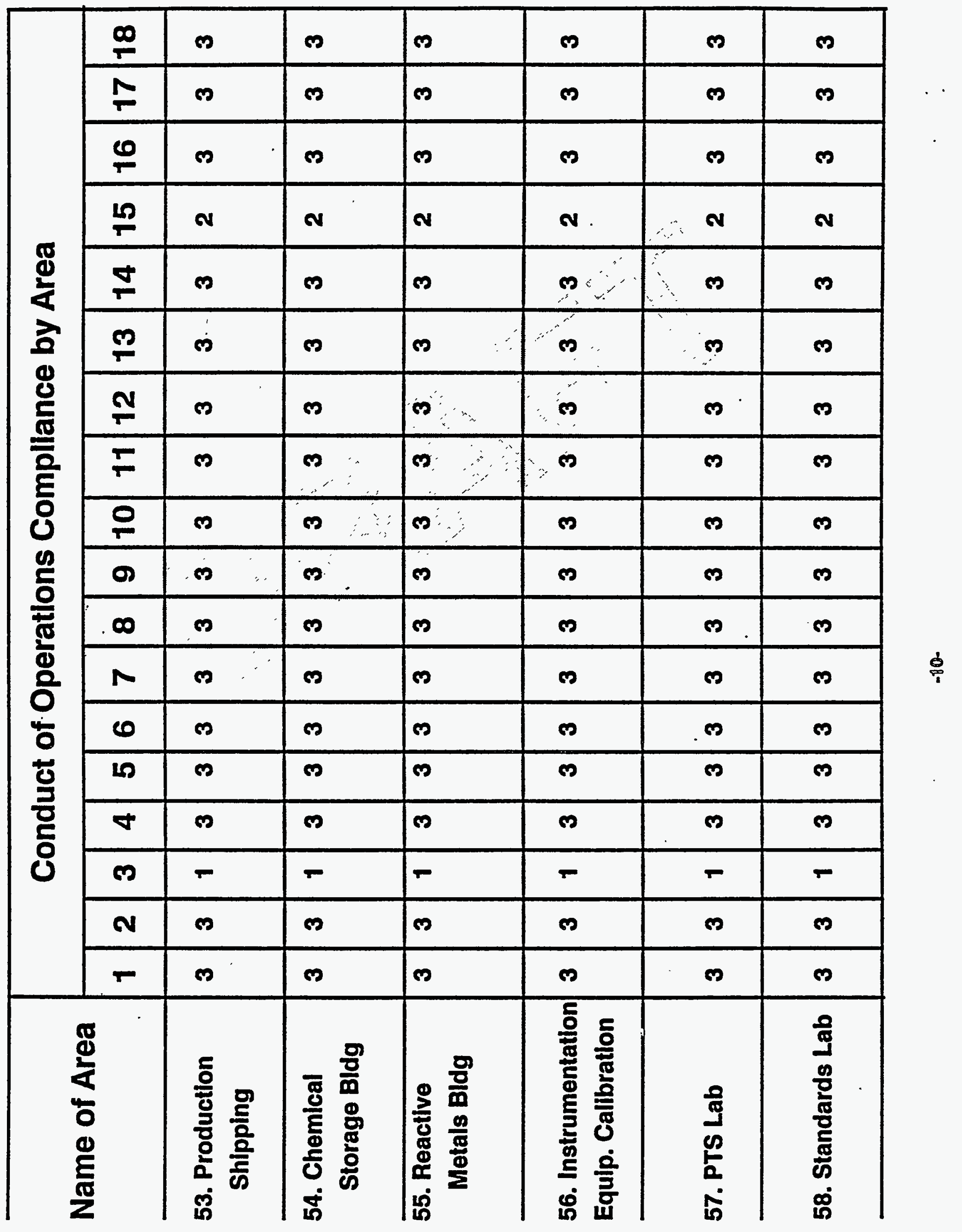




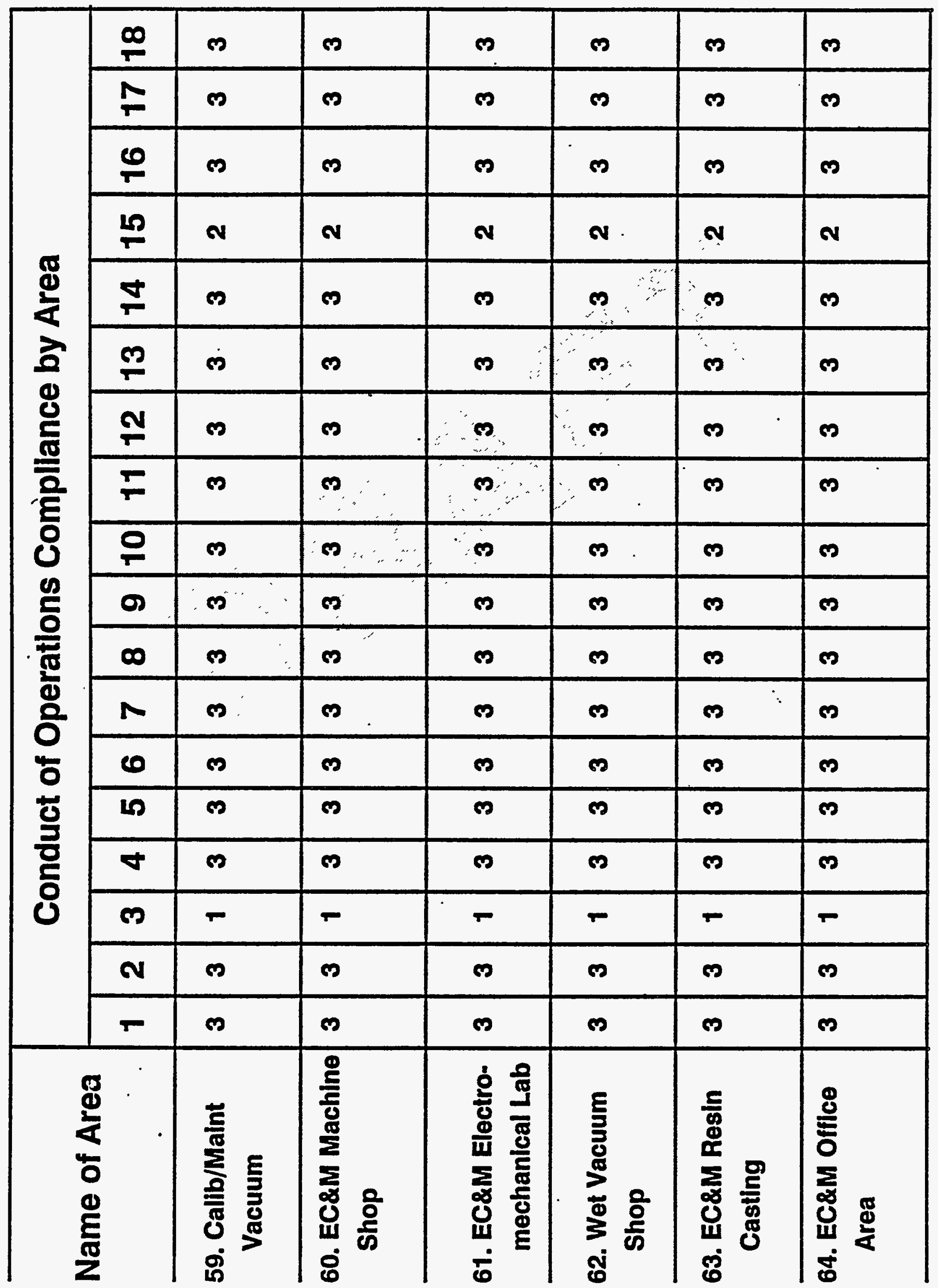




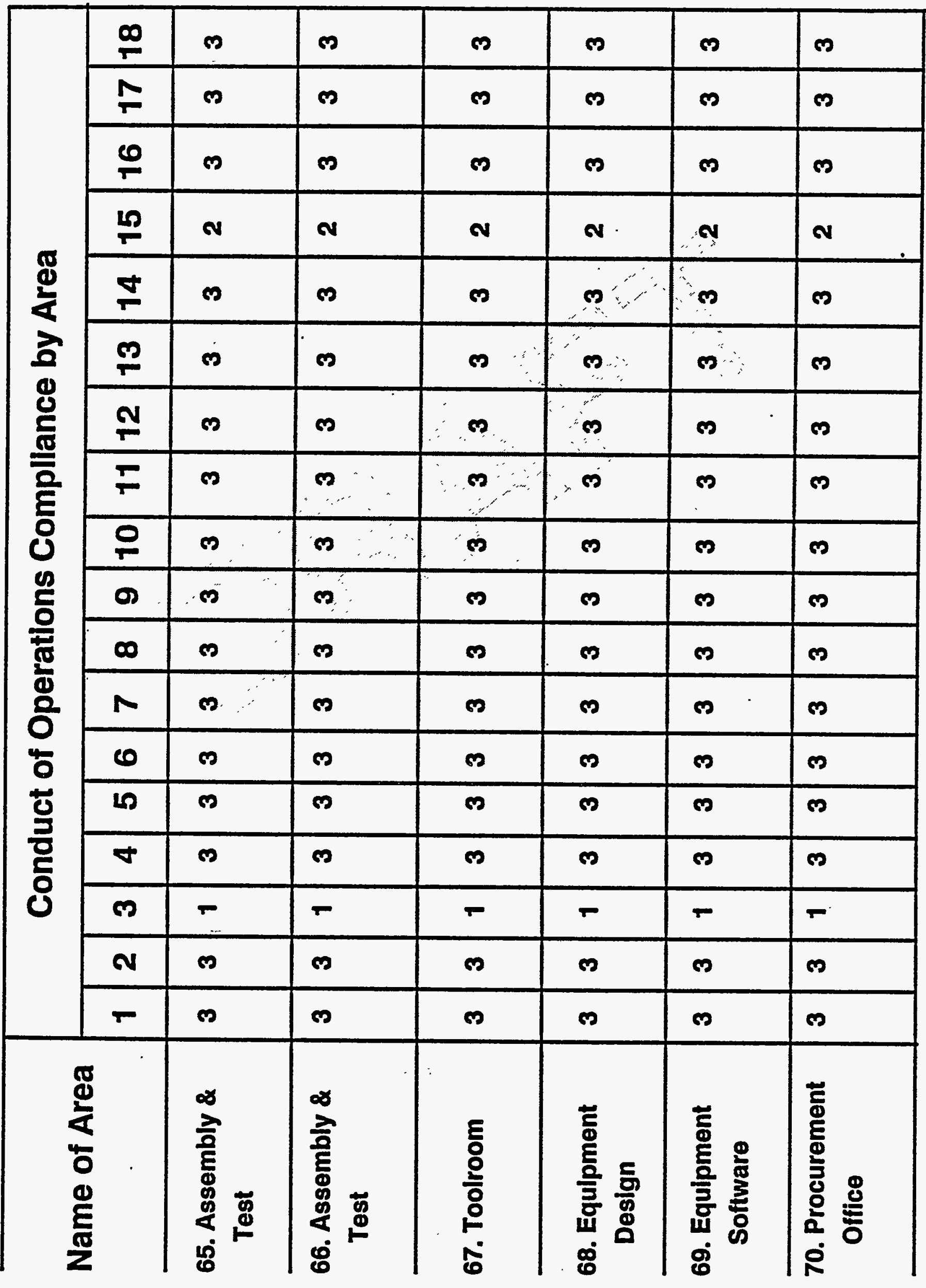




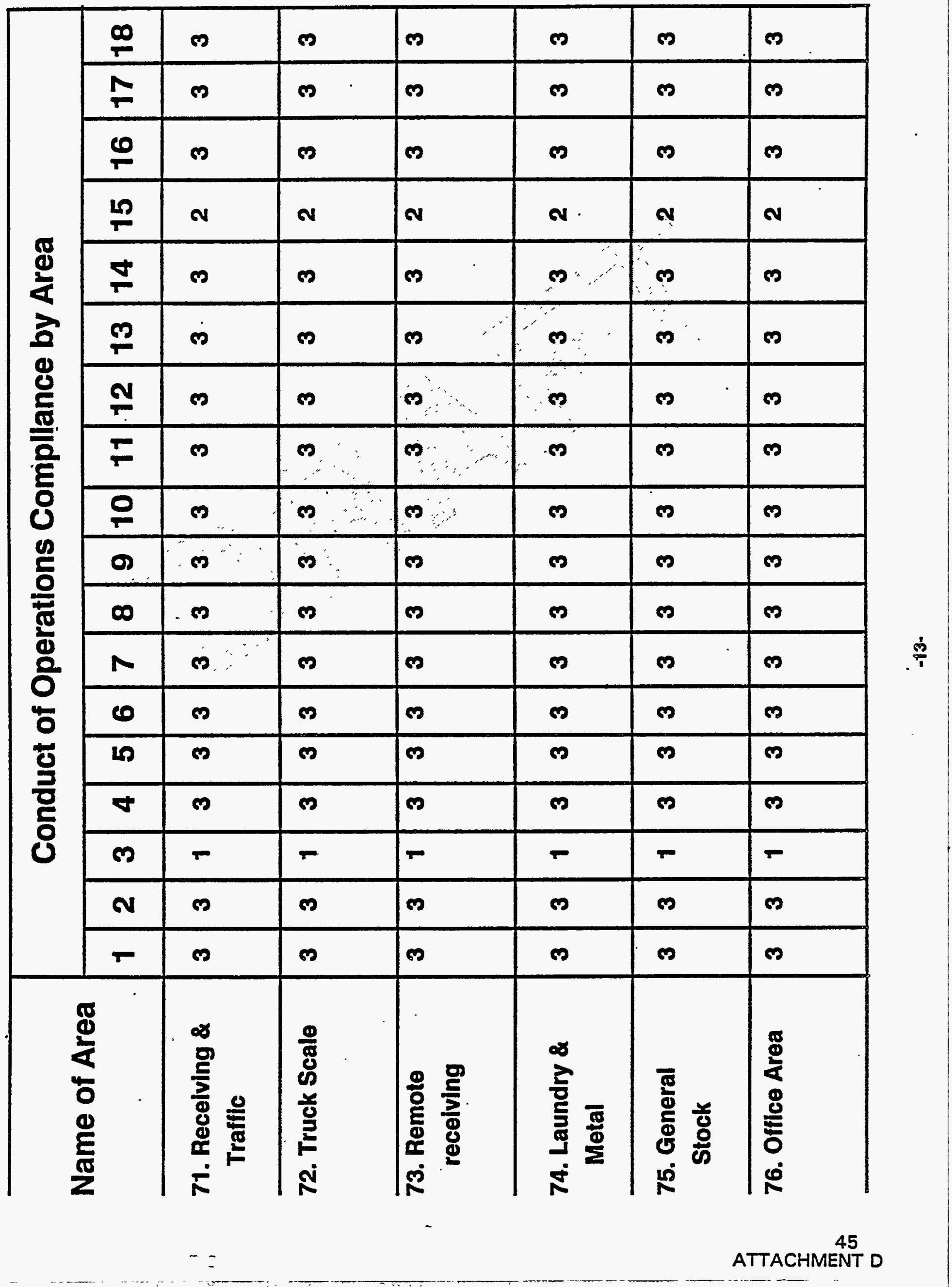




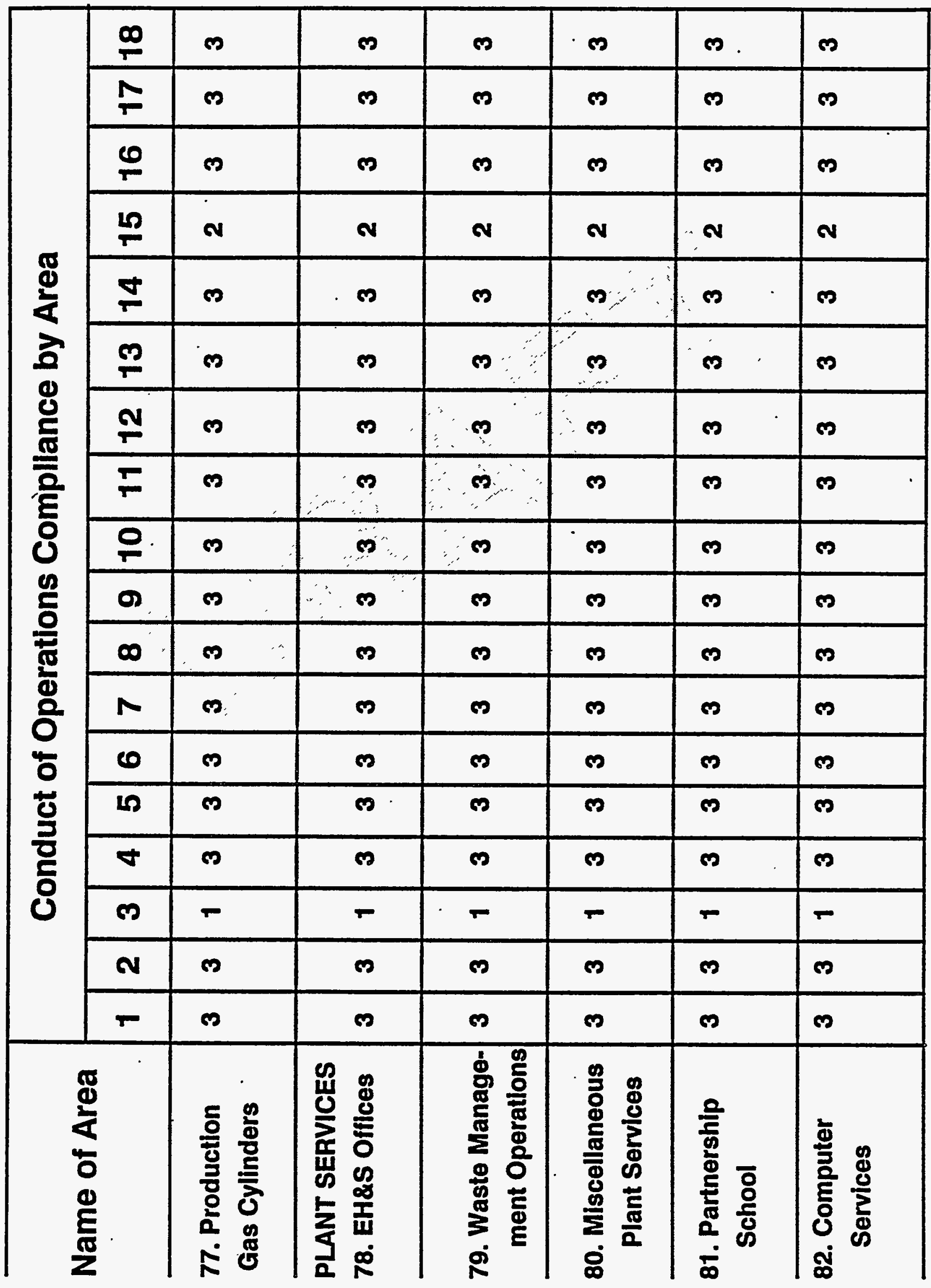




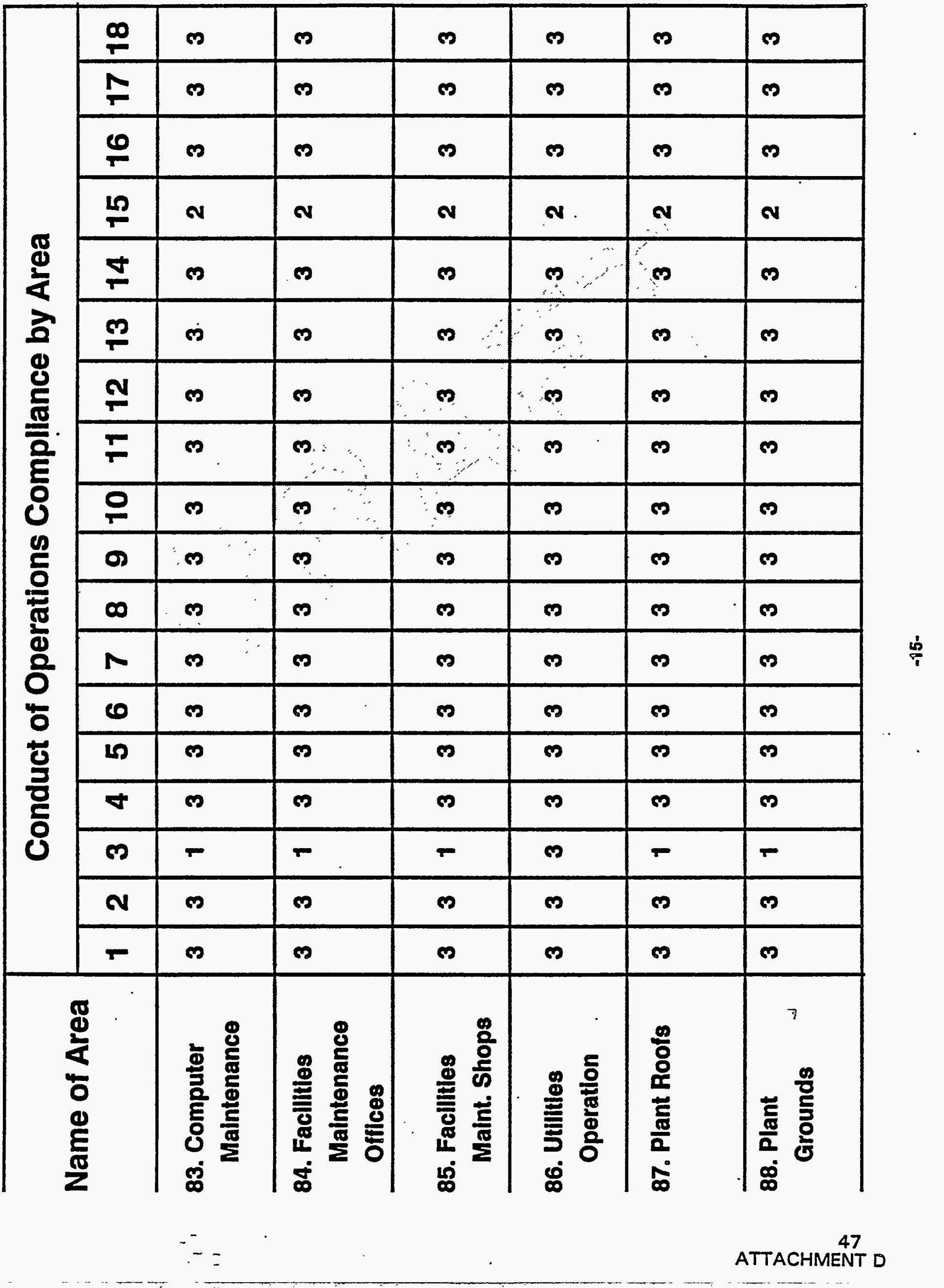




\begin{tabular}{|c|c|c|c|c|c|c|c|c|c|c|c|c|c|c|c|c|c|c|}
\hline \multirow{2}{*}{ Name of Area } & \multicolumn{18}{|c|}{ Conduct of Operations Compliance by Area } \\
\hline & 1 & 2 & 3 & 4 & 5 & 6 & 7 & 8 & 9 & 10 & 11 & 12 & 13 & 14 & 15 & 16 & 17 & 18 \\
\hline $\begin{array}{l}\text { 89.. Facilities } \\
\text { Equipment Rooms }\end{array}$ & 3 & 3 & 1 & 3 & 3 & 3 & 3 & 3 & 3 & 3 & 3 & 3 & 3. & 3 & 2 & 3 & 3 & 3 \\
\hline $\begin{array}{l}\text { 90. Fire Training } \\
\text { Facillitles }\end{array}$ & 3 & 3 & 1 & 3 & 3 & 3 & 3 & 3 & 3 & 3 & 3 & 3 & 3 & 3 & 2 & 3 & 3 & 3 \\
\hline $\begin{array}{l}\text { 91. Plant Facilities } \\
\text { Offices }\end{array}$ & 3 & 3 & 1 & 3 & 3 & 3 & 3 & 3 & 3 & 3 & 3 & 3 & 3 & 3 & 2 & 3 & 3 & 3 \\
\hline $\begin{array}{l}\text { 92. Plant } \\
\text { Security BIdg }\end{array}$ & 3 & 3 & 2 & 3 & 3 & 3 & 3 & 3 & 3 & 3 & 3 & 3 & 3 & 3 & 2 & 3 & 3 & 3 \\
\hline $\begin{array}{l}\text { 93. Emergency } \\
\text { Operations }\end{array}$ & 3 & 3 & 2 & 3 & 3 & 3 & 3 & 3 & 3 & 3 & 3 & 3 & 3 & 3 & 2 & 3 & 3 & 3 \\
\hline $\begin{array}{l}\text { 94. Cafeteria/ } \\
\text { Breakrooms }\end{array}$ & 3 & 3 & 1 & 3 & 3 & 3 & 3 & 3 & 3 & 3 & 3 & 3 & 3 & 3 & 2 & 3 & 3 & 3 \\
\hline
\end{tabular}




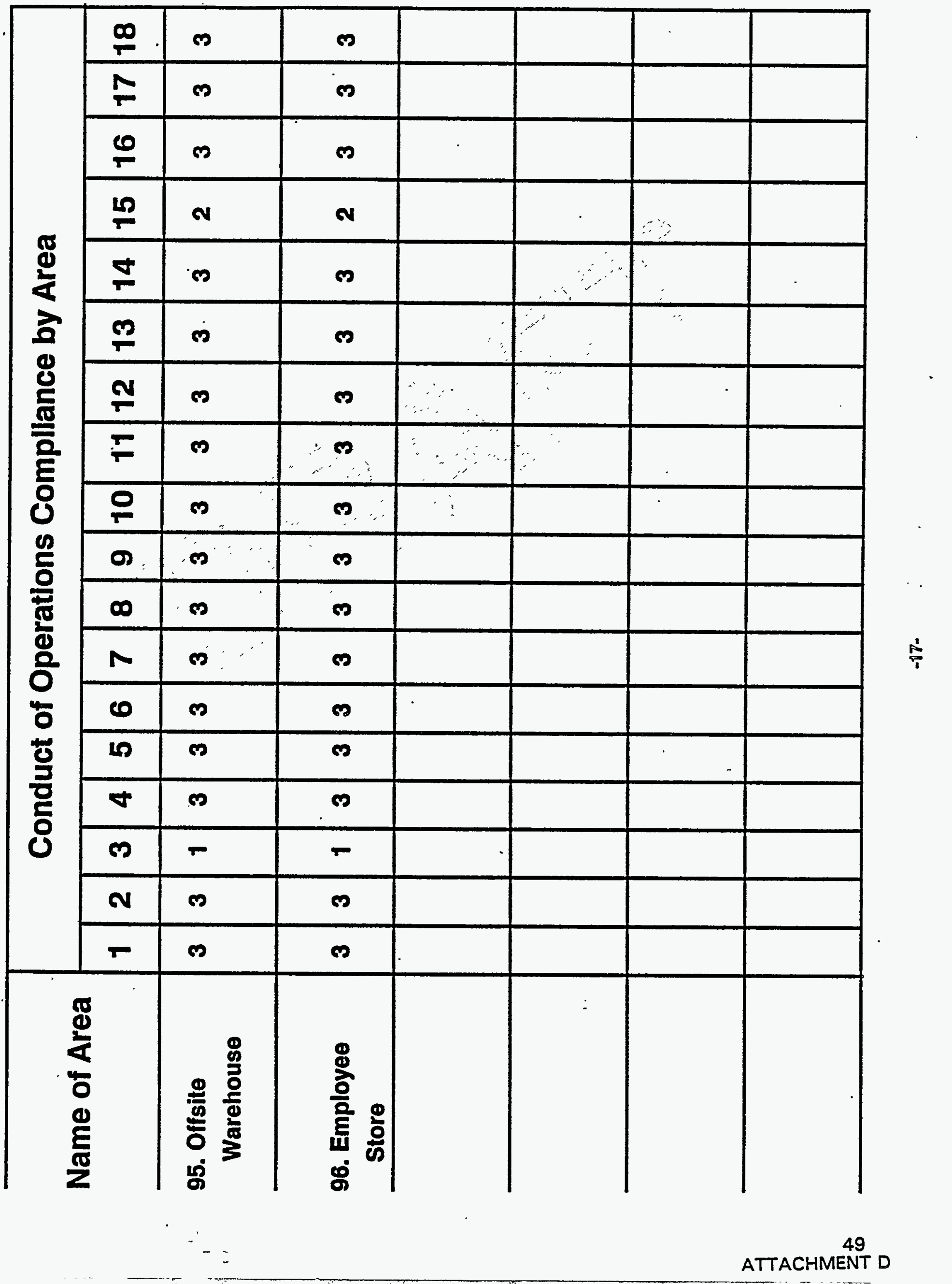





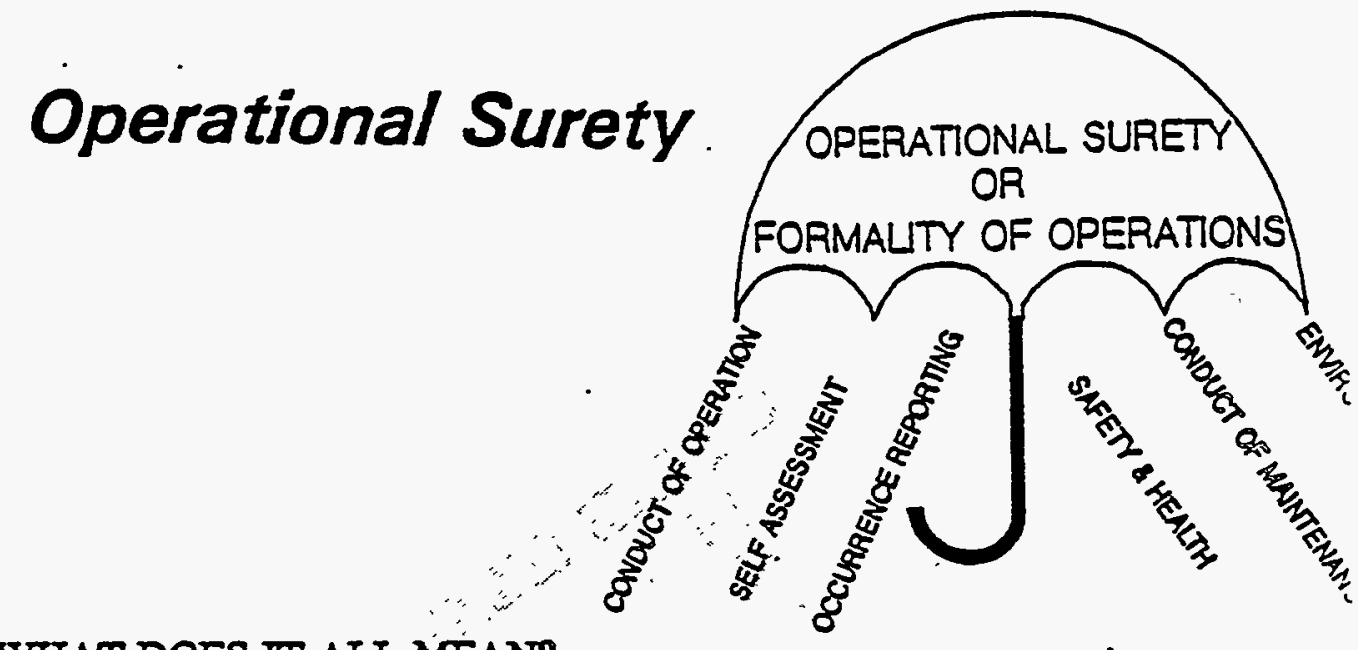

WHAT DOES IT AIL MEAN?

In general, these are terms used by our customer; the Deparment of Energy, in describing the new : standard for conducting business in the Nuclear Weapons Complex. Some of this new terminology refers to a specific DOE Order, while others describe the overall philosophy or program that encompasses ail the specific requirements.

Our Department recently focused many new resources toward meeting these new expectations. From Operational Surety Program Managers to Manufacturing and Engineering Operational Surety Managers to individual representatives on implementation teams, we will all be working toward a common goal - striving for business excellence with a comprehensive Operational Surety Program (OSP).

We hope to use this monthly newsletter to communicate these new programs and to speed the educational process we must all go through to inderstand this new way of doing business. In addition, watch the. Headliner for OSP communications.

In this first edition we would like to do two things. First, above is a graphical illustration of how it all workes. Operational Surety or Formality of Operations is the "umbrella" for all the individual elements we will implement. We will provide specific details of eact of these elements in future newsletters. Next, we thought you might be interested in an update on Occurrence Reporting, DOE Order 5000.3A.

If you have any questions, you may contact Melissa McCormick, Christy Anderson, Patsy Dillard, Linda Oberting or Bob Poole.

\section{OCCURRENCES}

$(5000.3 \mathrm{~A})$

We have had 36 occurrences since we started reporting the first of September. Here is a sample of what we have found to date:

1. Improper machining of lead

2. Water leaking from pipe from a radiological area.

3. Hydrogen hose fire:

4. Unresolved door alarm.

5. Disposal of SYNLUBE solution down storm drain.

6. Closure of Tape Vault resulting in personal injury.

A common thread or lesson learned through many occurrences is that we must spend more time planning the "non-routine" jobs we perform. Try to anticipate what might happen \& plan accordingly.

If you would like further details about these occurrences, check the Library for the file copy after November 29th. 


\section{OPERATIONAL SURETY NEWS \& VIEWS}

\section{WHAT DOES "CONDUCT OF OPERATIONS" (COOp) MEAN ?}

As all of you are aware, the Department of Energy (DOE) is establishing many new programs aimed at improving the safety, environment and health of the nuclear weapon facilities. Operation Programs is in the process of designing a communication tool to keep you informed of the implementation process of all the new DOE requirements, but for now we felt you needed some information to help you understand some of the basic terms.

Our first newsletter addressed the variety of new phrases popping up around the ( plant-Conduct of Operations, Operational Surety, Surveillance, etc. This edition provides a more in-depth description of one in particular.....DOE Order 5480.19, "Conduct of Operations" (COOp).

This order, which became effective July 9,1990 , identifies specific guidelines in a series of 18 chapters that must be implemented within each DOE facility to target the improvement of safety, the environment and health. Some examples of these 18 chapters are:

\section{- Lockout/Tagout Procedures \\ - Equipment and Pipe Labeling \\ - Logkeeping \\ - Shift Turnover Procedures}

The goal of the Department in requiring the implementation of each of these guidelines is to establish a more controlled method of operation. It is expected that the safety, environmental risk and human factors of every facility will be improved by establishing a more formal method of operation.

According to Christie Anderson, Program Manager for Conduct of Operations, "The - new Operation Programs organization in conjunction with the functional Operational Surety Managers is attempting to sift through this order, and many others that are directly related, to identify what parts are applicable and could benefit NDD."

Initially, the CoOp guidelines are being implemented in two pilot areas, the Industrial Wastewater Neutralization Facility and lab area 182D. You will be hearing more about CoOp and how it will affect you as more specific plans are developed and communicated. An educational video on Conduct of Operations will be available soon along with training modules on all of the 18 requirements.

So, the next time you hear one of these often used phrases,

\section{"CONDUCT OF OPERATIONS... OPERATIONAL SURETY...SURVEILLANCES",}

don't be confused, it is just a new way of operating NDD to assure that we are all safe and that the environment is protected. There will be many, many more programs of this type being developed and we will keep you informed through this newsletter. A copy of the DOE Order 5480.19 is available for reading in the Technical Information Center (TIC). If your department is already implementing CoOp, let us know, we'll feature you in future issues. 


\section{INCIDENTS \& OCCURRENCES (5000.3A)}

As previously mentioned, surveillance is becoming a critical part of our jobs. An important aspect of this surveillance is the 5000.3A occurrence reporting. Here are some of the recent occurrences reported from our plant.

- Sulfur Dioxide Monitor failure in LAMB area.

- $\quad$ Plugged pressure relief valve (reference the Safety Flash of 1/25/91).

- Portable fire extinguisher inspection program out of NEPA Specifications.

- Improper disposal of a classified mold.

- Electrical Shock of a craftsman.

- Finger laceration of a craftsman.

- Three Uninteruptible Power Supply (UPS) failures.

- Head injury of a craftsman while operating a lift-a-loft (see details below).

\section{FACTS ABOUT THE LIFT-A-LOFT INJURY.}

- On Monday, January 28 at about 4:45pm, a Maintenance Craftsman was injured while operating a lift-a-loft.

- His head was caught between the lift-a-loft cage and the concrete lintel (doorway) just west of the cafeteria.

- NDD emergency personnel responded immediately and within 15 minutes of the incident, Pinellas County EMS arrived. The Bayflight helicopter lifted the craftsman to Bayfront Medical within 30 minutes of the accident.

- The craftsman is in the hospital listed as stable and improving.

\section{CORRECTIVE ACTIONS}

- The lift-a-loft was inspected and found to be in good operating order.

- All lift-a-lofts have been tagged-out pending further investigation.

- An Accident Investigation Team has been created to perform a MORT (Management Oversight \& Risk Tree) based root cause analysis. The Team is chaired by the DOE Branch Chief of Environment, Safety \& Health, and Compliance, and includes NDD representatives from Facilities, Human Resources, and EH\&SP. A consultant has been retained to provide technical guidance as needed.

How safe do you feel on your job? Have you received the proper training on all machinery that you're expected to operate? Challenge your managers, it's their obligation to be sure that you are aware of all available information. Managers, if you're not aware of what's available, call any Operational Surety Program Manager.

\section{TO BE SAFE, BE ALERT}

91-01 This newsletter is published by Operation Programs for the employees of the Neutron Devices Department which operates the Pinellas Plant for the United States Department of Energy. For information or questions pertaining to any of the contents, contact: Leslie Daniels, Operation Programs, X6702. 


\section{ATTACHMENT F}




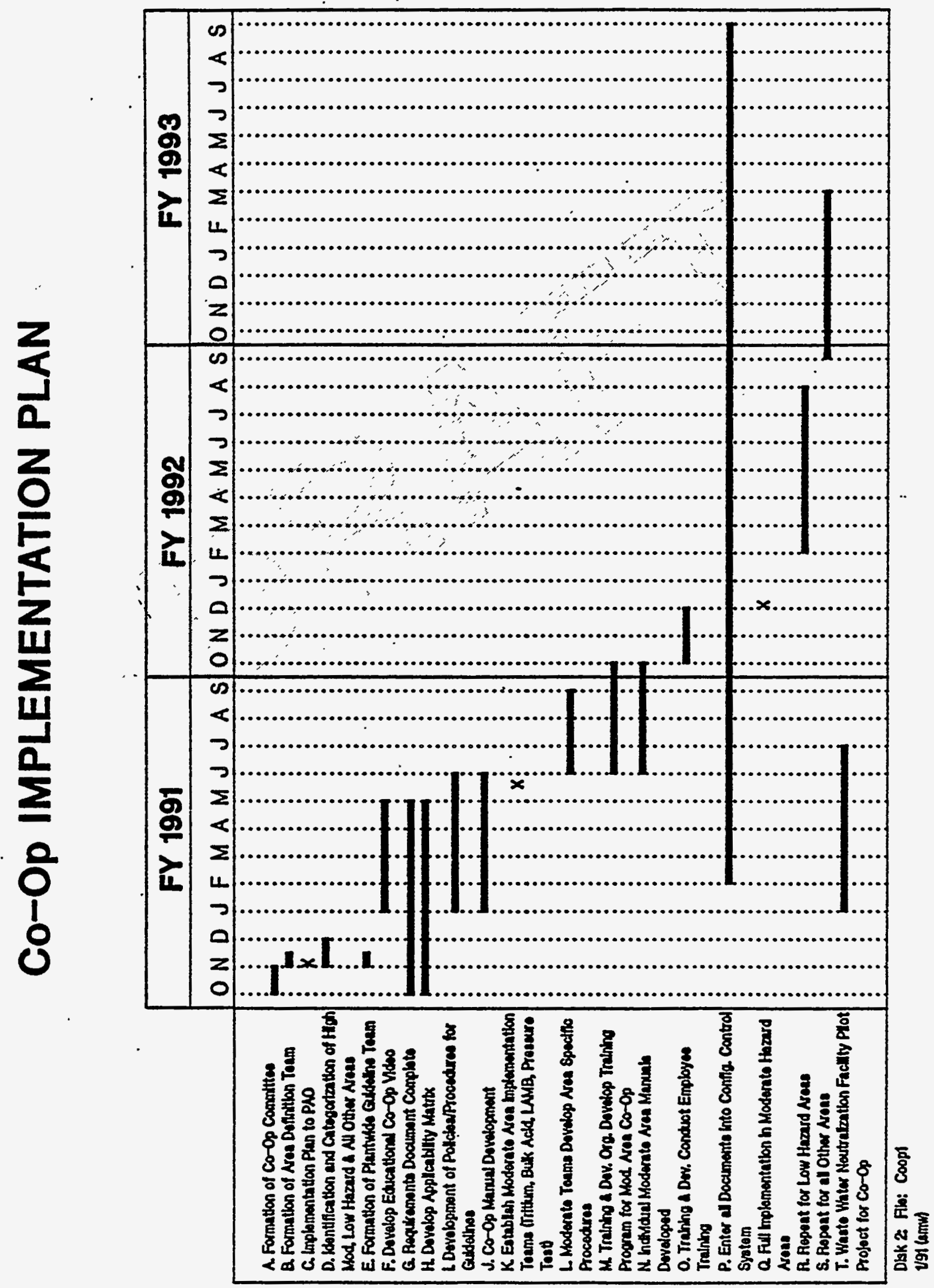




\section{CONDUCT OF OPERATIONS}

\section{IMPLEMENTATION SCHEDULE, Continued.}

A. Formation of Co-Op Committee - Refer to Conduct of Operátions Implementation Plan NDPP-OSP-0003

B. Formation of Area Definition Team - Refer to NDPP-OSP-0003

C. Implementation Plan to PAO - Refer to Title Page NDPP-OSP-0003.

D. Identification and Categorization of High, Mod, Low Hazard \& All Other Areas - Refer to Paragraph 7.2.1

E. Formation of Plantwide Guideline Team - Refer to Paragraph 7.2.2

F. Develop Educational Co-Op Video - Refer to Paragraph 9.1.2

G. Requirements Document Complete - Draft outline completed

H. Develop Applicability Matrix - Refer to Paragraph 7.5

I. Development of Policies/Procedures for Guidelines - Refer to Paragraph 7.2.2

J. Co-Op Manual Development - Refer to Paragraph 8.0

K. Establish Moderate Area Implementation Teams (Tritium, Bulk Acid, LAMB, Pressure Test) - Refer to Paragraph 7.2.3

L. Moderate Teams Develop Area Specific Procedures - Refer to 7.2.3

M. Training \& Dev. Org. Develop Training Program for Mod. Area Co-Op - Refer to Paragraph 9.2

N. Individual Moderate Area Manuals Developed - Refer to Paragraph 8.2

O. Training \& Dev. Conduct Employee Training - Refer to Paragraph 9.2

P. Enter all documents into Config. Control System - Refer to Paragraph 8.1

Q. Full Implementation in Moderate Hazard Areas - Refer to complete plan NDPP-OSP-0003

R. Repeat for Low Hazard Areas - Steps I through Q will be repeated for Low Hazard Areas.

S. Repeat for all other areas - Steps $\mathrm{L}$ through $\mathrm{Q}$ will be repeated for all other areas.

T. Wastewater Neutralization Facility Pilot Project for Co-Op - Refer to Paragraph 7.6. 


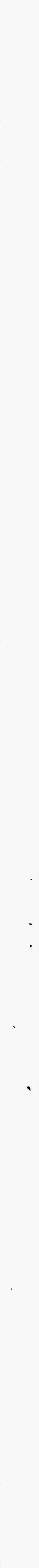




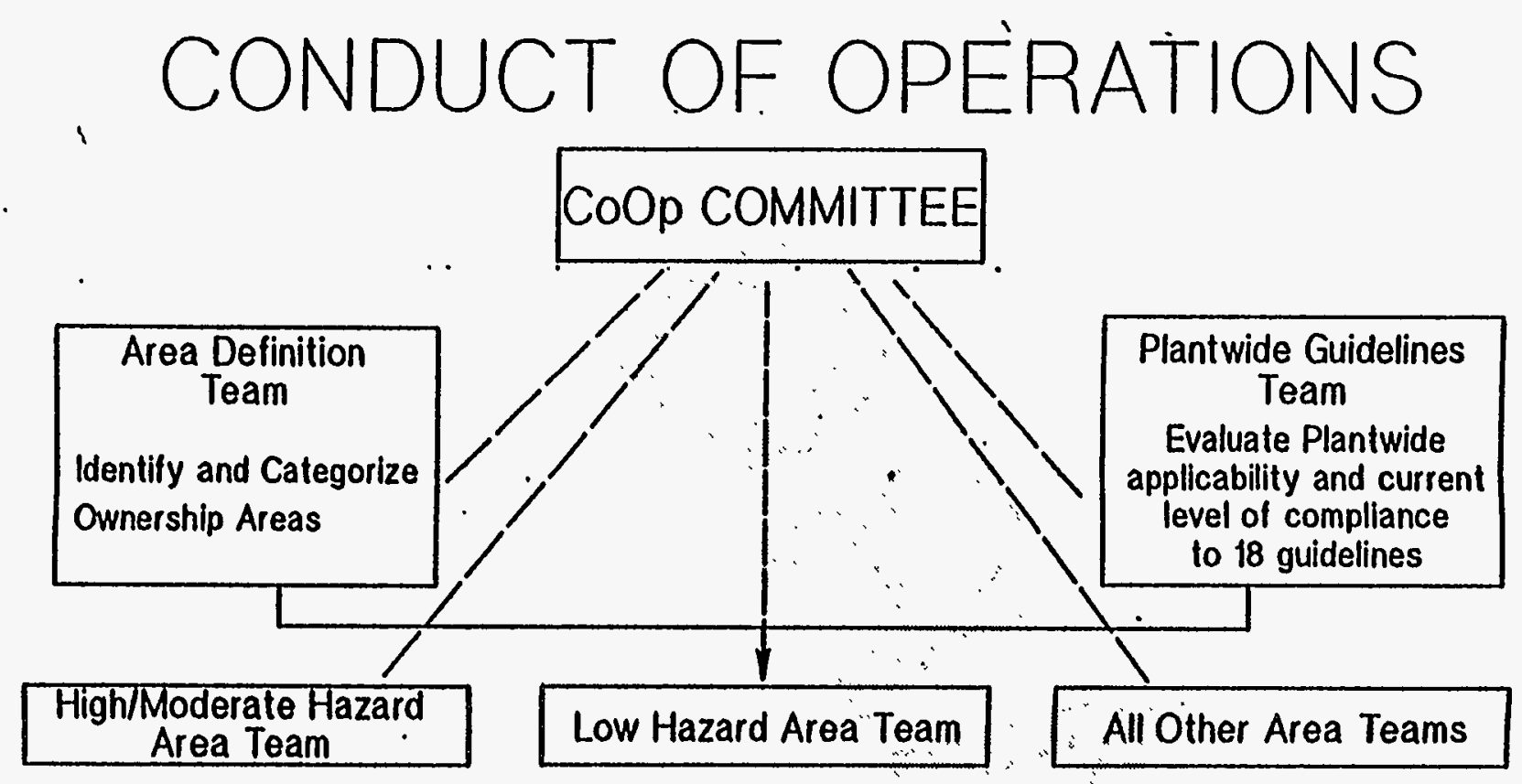

* Assess area specific level of compliance to guldelines

* Determine Applicability

* Document Rationale

* Develop Policy

* Recommend Survelllance

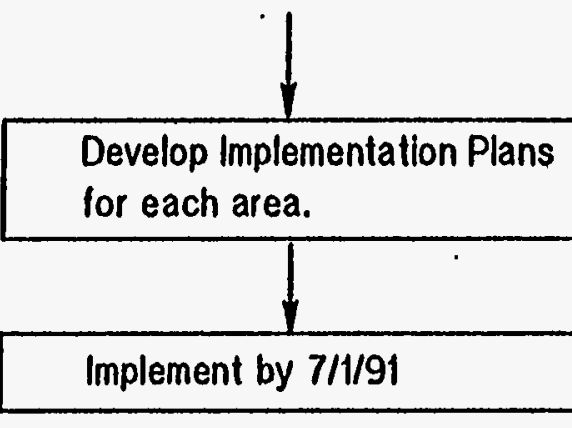




\section{ATTACHMENT H .}


FUNDING PROFILE FOR IMPLEMENTATION OF CONDUCT OF OPERATIONS

\begin{tabular}{|c|c|c|c|c|}
\hline & FY91 & FY92 & FY93 & TOTAL \\
\hline HEADCT/FTE'S \# • & 8 & 8 & 8 & 8 \\
\hline HEADCT/FTE'S \$\$ * * & $\$ 484,000$ & $\$ 508,800$ & $\$ 508,800$ & $\$ 1,501,600$ \\
\hline OTHER \$\$ ** & $1,015,000$ & 752,500 & 202,500 & $1,970,000$ \\
\hline TOTAL & $\$ 1,499,000$ & $\$ 1,261,300$ & $\$ 711,300$ & $\$ 3,471,600$ \\
\hline
\end{tabular}

Planned actions can only be accomplished within the indicated scheduled if sufficient funding is provided in those years.

* Total includes 4 CoOp Engineers for functional implementation, 2 Technical Writers/Editors ${ }_{i}$ and 2 Requirements Engineers/Specialists.

* Manpower costs are average salary plus benefits. Manpower costs for FY93 are not escalated.

** "Other $\$ \$ "$ includes expenses related to training, re-arrangement, equipment, travel and miscellaneous. 